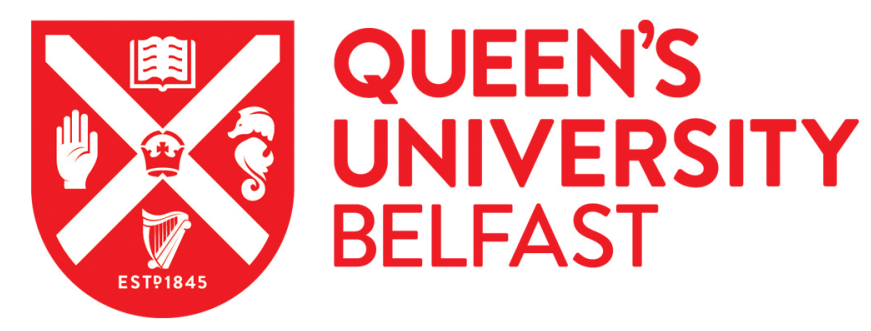

\title{
Rational design and characterisation of an amphipathic cell penetrating peptide for non-viral gene delivery
}

McErlean, E. M., McCrudden, C. M., McBride, J. W., Cole, G., Kett, V. L., Robson, T., Dunne, N. J., \& McCarthy, H. O. (2021). Rational design and characterisation of an amphipathic cell penetrating peptide for non-viral gene delivery. International Journal of Pharmaceutics, 596, [120223]. https://doi.org/10.1016/j.ijpharm.2021.120223

\section{Published in:}

International Journal of Pharmaceutics

\section{Document Version:}

Peer reviewed version

\section{Queen's University Belfast - Research Portal:}

Link to publication record in Queen's University Belfast Research Portal

\section{Publisher rights}

Copyright 2021 Elsevier.

This manuscript is distributed under a Creative Commons Attribution-NonCommercial-NoDerivs License

(https://creativecommons.org/licenses/by-nc-nd/4.0/), which permits distribution and reproduction for non-commercial purposes, provided the author and source are cited.

\section{General rights}

Copyright for the publications made accessible via the Queen's University Belfast Research Portal is retained by the author(s) and / or other copyright owners and it is a condition of accessing these publications that users recognise and abide by the legal requirements associated with these rights.

Take down policy

The Research Portal is Queen's institutional repository that provides access to Queen's research output. Every effort has been made to ensure that content in the Research Portal does not infringe any person's rights, or applicable UK laws. If you discover content in the Research Portal that you believe breaches copyright or violates any law, please contact openaccess@qub.ac.uk. 


\section{International Journal of Pharmaceutics \\ Rational Design and Characterisation of an Amphipathic Cell Penetrating Peptide for Non-Viral Gene Delivery \\ --Manuscript Draft--}

\begin{tabular}{|c|c|}
\hline Manuscript Number: & IJP-D-20-01960R1 \\
\hline Article Type: & Research Paper \\
\hline Section/Category: & Pharmaceutical Nanotechnology \\
\hline Keywords: & Nanoparticle; Cell Penetrating Peptide; RALA; Amphipathic Peptide; Gene Delivery \\
\hline Corresponding Author: & $\begin{array}{l}\text { Helen O McCarthy, United Kingdom } \\
\text { Queen's University Belfast } \\
\text { Belfast, UNITED KINGDOM }\end{array}$ \\
\hline First Author: & Emma M McErlean, PhD \\
\hline \multirow[t]{8}{*}{ Order of Authors: } & Emma M McErlean, PhD \\
\hline & Cian M McCrudden, PhD \\
\hline & John W McBride, PhD \\
\hline & Grace Cole, PhD \\
\hline & Vicky L Kett, PhD \\
\hline & Tracy Robson, PhD \\
\hline & Nicholas J Dunne, PhD \\
\hline & Helen O McCarthy, United Kingdom \\
\hline Abstract: & $\begin{array}{l}\text { RALA is a cationic amphipathic peptide which has shown great promise as an efficient, } \\
\text { multifunctional delivery system for the delivery of nucleic acids. Rational peptide design } \\
\text { was utilised in this study to understand the essential amino acids required for delivery } \\
\text { and if any improvements to the RALA peptide could be made. Six amphipathic } \\
\text { peptides were synthesised with strategic sequences and amino acid substitutions to } \\
\text { reduce peptide sequence while maintaining the functional characteristics of RALA } \\
\text { including amphipathicity, alpha-helicity and pH responsiveness for endosomal escape. } \\
\text { Data demonstrated that all six peptides complexed pEGFP-N1 to produce cationic } \\
\text { nanoparticles less than } 200 \mathrm{~nm} \text { in diameter, but not all peptides resulted in successful } \\
\text { transfection; indicating the influence of peptide design for cellular uptake and } \\
\text { endosomal escape. Pep2, produced nanoparticles with similar characteristics and } \\
\text { transfection efficiency to parent RALA. However, Pep2 had issues with toxicity and a } \\
\text { lack of pH-responsiveness. Therefore, RALA remains the superior sequence for non- } \\
\text { toxic gene delivery. }\end{array}$ \\
\hline
\end{tabular}



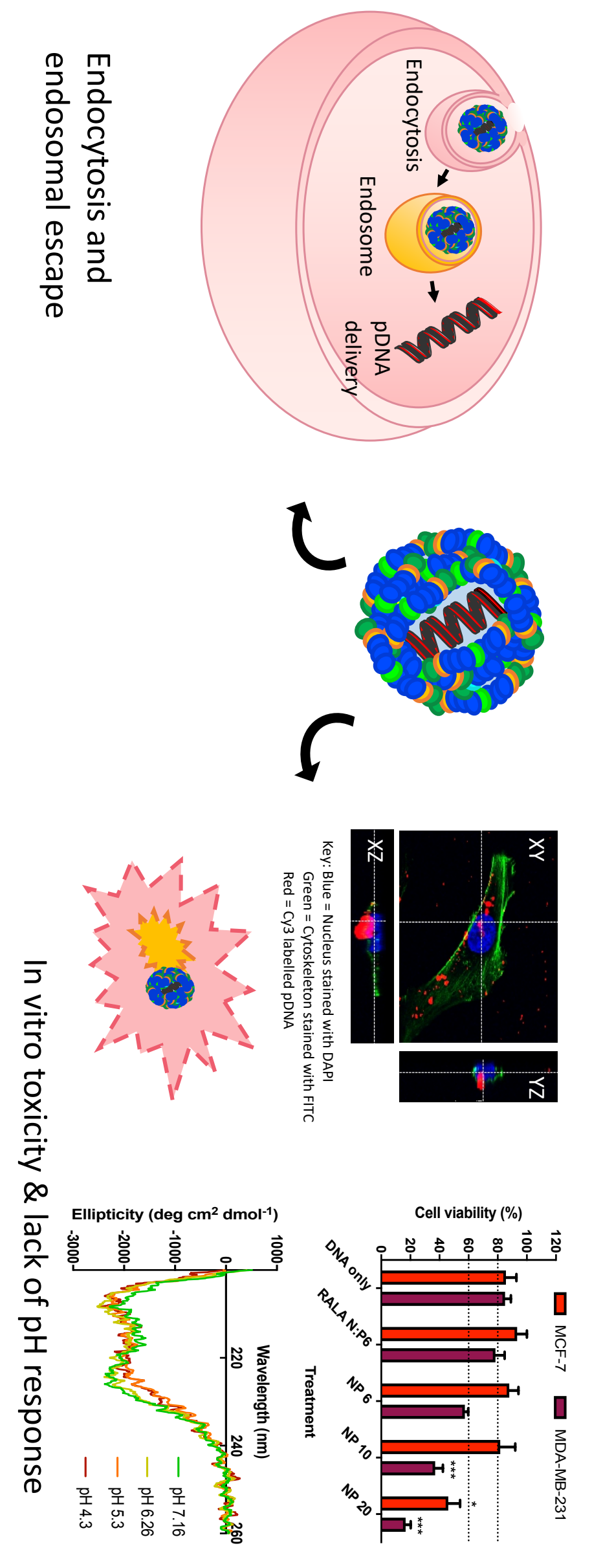

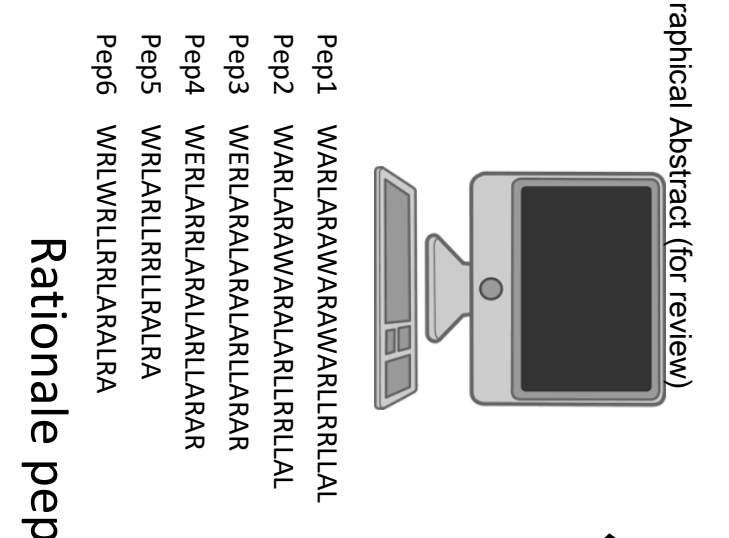

$\frac{0}{2}$
$\frac{0}{0}$
0
$\frac{0}{0}$
$\frac{0}{0 .}$
$\frac{0}{2}$
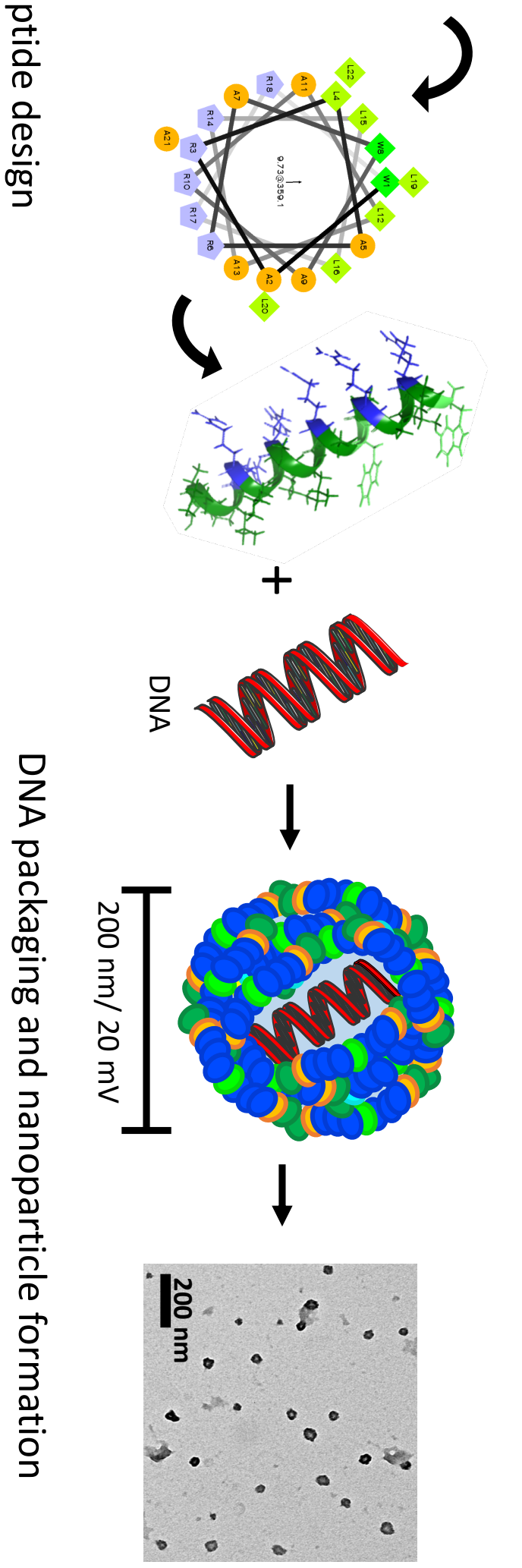

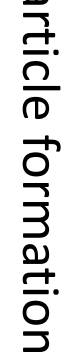

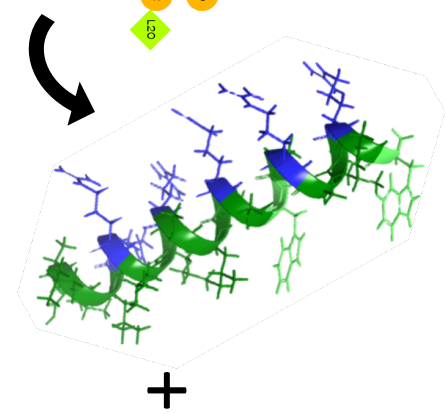




\title{
Rational Design and Characterisation of an Amphipathic Cell Penetrating Peptide for Non- Viral Gene Delivery
}

\author{
Emma M. McErlean ${ }^{1}$, Cian M. McCrudden ${ }^{1}$, John W. McBride ${ }^{1}$, Grace Cole ${ }^{1}$, Vicky L. \\ Kett $^{1}$, Tracy Robson ${ }^{2}$, Nicholas J Dunne ${ }^{1,3-9}$, Helen O McCarthy ${ }^{1,10}$.
}

\begin{abstract}
${ }^{1}$ School of Pharmacy, Queen's University Belfast, 97 Lisburn Road, Belfast BT9 7BL, UK
${ }^{2}$ School of Pharmacy and Biomolecular Sciences, Royal College of Surgeons Ireland, 111 St Stephen's Green Dublin 2

${ }^{3}$ School of Mechanical and Manufacturing Engineering, Dublin City University, Dublin 9, Ireland.

${ }^{4}$ Centre for Medical Engineering Research, School of Mechanical and Manufacturing Engineering, Dublin City University, Dublin 9, Ireland.
\end{abstract}

${ }^{5}$ Department of Mechanical and Manufacturing Engineering, School of Engineering, Trinity College Dublin, Dublin 2, Ireland.

${ }^{6}$ Advanced Manufacturing Research Centre (I-Form), School of Mechanical and Manufacturing Engineering, Dublin City University, Glasnevin, Dublin 9, Ireland

${ }^{7}$ Advanced Materials and Bioengineering Research Centre (AMBER), Royal College of Surgeons in Ireland and Trinity College Dublin, Dublin, Ireland.

${ }^{8}$ Advanced Processing Technology Research Centre, Dublin City University, Dublin 9, Ireland.

${ }^{9}$ Trinity Centre for Biomedical Engineering, Trinity Biomedical Sciences Institute, Trinity College Dublin, Dublin 2, Ireland.

${ }^{10}$ School of Chemical Sciences, Dublin City University, Dublin 9, Ireland

\section{Abstract}

RALA is a cationic amphipathic peptide which has shown great promise as an efficient, multifunctional delivery system for the delivery of nucleic acids. Rational peptide design was utilised in this study to understand the essential amino acids required for delivery and if any improvements to the RALA peptide could be made. Six amphipathic peptides were synthesised with strategic sequences and amino acid substitutions to reduce peptide sequence, while maintaining the functional characteristics of RALA including amphipathicity, alpha-helicity 
and $\mathrm{pH}$ responsiveness for endosomal escape. Data demonstrated that all six peptides complexed pEGFP-N1 to produce cationic nanoparticles less than $200 \mathrm{~nm}$ in diameter, but not all peptides resulted in successful transfection; indicating the influence of peptide design for cellular uptake and endosomal escape. Pep2, produced nanoparticles with similar characteristics and transfection efficiency to the parent peptide, RALA. However, Pep2 had issues with toxicity and a lack of pH-responsive alpha-helcity. Therefore, RALA remains the superior sequence for non-toxic gene delivery.

\section{Introduction}

The ideal gene delivery vector must be cost efficient, non-toxic, non-immunogenic, overcome extra- and intra-cellular barriers and protect the nucleic acid cargo from degradation, with stability over a range of temperatures. The most efficient gene delivery agents are viral vectors, but difficulties with large scale production, limitations of cargo size and uncertainties about mutagenesis, toxicity, immunogenicity and costs need to be navigated before becoming a product [1-3]. Consequently, much research is now focused on the design of non-viral vectors, which have the potential to circumvent the problems associated with viral vectors [4]. However, transfection efficiency using non-viral vectors remains significantly lower than viral vectors, and improvements are still required [5].

RALA (WEARLARALARALARHLARALARALRACEA) is a peptide shown to be highly effective as a multifunctional delivery system for a range of nucleic acids such as DNA, mRNA, siRNA and small molecules such as bisphosphonates [6-9]. The peptide sequence and structure of RALA has a major impact on functionality. RALA is a 30-mer cationic amphipathic helical peptide, which contains seven hydrophilic arginine residues localised on one face of the helix, with hydrophobic leucine residues localised on the opposite face. The arginine residues give RALA a cationic nature which is integral for packaging of nucleic acids 
and electrostatic interaction with cell membranes [10-12]. The amphipathic conformation is also important for interaction with lipophilic cell membranes $[13,14]$, and the combination of cationicity and amphipathicity give RALA a strong cell penetrating and fusogenic activity leading to impressive transfection efficiencies. However, transfection efficiency can vary depending on the cell line. A more consistent transfection performance across various cell types is highly desirable and allows for a wide range of applications. In addition, the lengthy 30-mer sequence of RALA results in expensive production; a shorter amino acid sequence could may reduce costs considerably. Therefore, the aim is to produce a shorter RALA sequence which is functionally equal or greater than RALA, while reducing costs. This study examined whether a truncated RALA derivative peptide, to supersede RALA, could be generated.

The RALA peptide sequence is characterised by repeat units of arginine (R), alanine (A), leucine (L) and alanine (A), R-A-L-A, which gives rise to the amphipathic nature of the peptide. Figure 1 allows the visualisation of the amphipathic structure and helical conformation of RALA. There is a clear separation between hydrophobic and hydrophilic residues and the adoption of an $\alpha$-helical structure may be facilitated by membrane associated proteoglycans which have been shown to be integral for clathrin mediated endocytosis [15]. In the case of RALA, circular dichroism confirmed that $\sim 30 \%$ of RALA exists in an $\alpha$-helical conformation at a physiological $\mathrm{pH}$ with the majority of the peptide in random coil formation which aids cellular entry [6]. When the $\mathrm{pH}$ drops inside the endosome, there is a corresponding increase in the $\alpha$-helicity of RALA, which is necessary for endosomal escape and release of the cargo. Thus, it is important that derivative peptides possess similar amphipathic $\alpha$-helical conformations. 
RALA is rich in arginine and it is well established that peptides containing basic residues (arginine, lysine and histidine) are highly efficient in enabling binding and delivery of pEGFPN1 into cells [16]. RALA contains seven arginine residues, which is within the optimal range for cell penetration and low toxicity $[14,17,18]$. Therefore, arginine has a key role and should be retained in any derivative peptides [19].

Hydrophobicity is an important factor for interaction with cell membranes and tryptophan confers hydrophobicity on amphipathic peptides. Examples of tryptophan-rich peptides include $\begin{array}{lll}\text { CADY (GLWRALWRLLRSLWRLLWRA) } & \text { and }\end{array}$ (GLWWRLWWRLRSWFRLWFRA), which are highly efficient synthetic amphipathic peptides reported to penetrate cell membranes [19]. Rational peptide design was used to produce CADY, by using ppTG1 as a template [20]. Arginine (R) and tryptophan (W) residues were substituted into the sequence and the resultant CADY peptide formed stable complexes with siRNA, thereby increasing stability and improving delivery into various cell lines [21]. It has also been reported that the $\mathrm{pH}$-dependent membrane-disruptive properties of fusogenic peptides, such as RALA, correlate with the protonation of glutamate or aspartate residues at a lower $\mathrm{pH}$ [22]. It is integral that derivative peptides retain this $\mathrm{pH}$-responsive nature for endosomal escape and glutamic acid will therefore be included in the design process.

Six peptides have been rationally designed in pairs (Table 1) with criteria as follows; (i) reduction of peptide sequence length, while maintaining function, amphipathic structure and cationic nature; (ii) reduction in number of arginine residues to six, which has been stated as the minimum number required for cellular uptake [14,18]; (iii) introduction of tryptophan residues and substitution of leucine residues for hydrophobic interaction with cell membranes, 
maintain amphipathic helical structure and minimise potential cytotoxicity [23], (iv) inclusion of glutamic acid to assess influence on $\mathrm{pH}$-responsive activity.

\section{Methods and Materials}

\subsection{Materials}

\subsubsection{Peptides}

All peptides were produced by solid state synthesis (fluorenylmethoxycarbonyl (FMOC) chemistry) (Biomatik, Canada) and supplied as a lyophilised powder which required reconstitution before use. Peptides were supplied in the acetate salt form and were of $>95 \%$ purity. After cleavage from the resin the desired products were purified by and confirmed by Reverse Phase High Performance Liquid Chromatography (RPHPLC).

\subsubsection{Plasmid DNA}

pEGFP-N1 was purchased from Clontech (USA). Plasmid DNA (pEGFP-N1) was propagated in MAX Efficiency ${ }^{\circledR}$ DH5 $\alpha^{\mathrm{TM}}$ Competent Cells (Life Technologies, UK), purified using PureLink ${ }^{\circledR}$ HiPure Plasmid Filter Maxiprep Kit (Life Technologies, UK) and quantified by UV absorption at $260 \mathrm{~nm}$.

\subsubsection{Cell lines}

MCF-7 and MDA-MB-231 breast cancer cells (ATCC, Manassas, VA) were maintained as monolayers in Dulbecco's Modified Eagle's Medium (DMEM) (Invitrogen, UK) supplemented with $10 \%$ foetal calf serum (FCS). DU145 and PC-3 prostate cancer cells were maintained as monolayers in Roswell Park Memorial Institute medium (RPMI) supplemented with 10\% FCS. When cells reached approximately $80 \%$ confluency they were passaged and were not used for experimental protocols beyond a passage number of 20. Cells were maintained in an incubator 
at $37^{\circ} \mathrm{C}$ with $5 \% \mathrm{CO}_{2}$ atmosphere and subjected to mycoplasma testing routinely. All in vitro cell experiments were carried out at $37^{\circ} \mathrm{C}$ in a $5 \% \mathrm{CO}_{2}$ incubator. All cell lines were authenticated by short tandem repeat (STR) profiling carried out by the suppliers.

\subsection{Methods}

\subsubsection{Design and synthesis of novel peptides}

Six amphipathic peptides were rationally designed and sequences of the novel amphipathic peptides are shown in Table 1. Helical wheel projections, 3D structure modelling using Maestro 3D structure prediction software (version 12.2.012, Schrodinger, Germany) and the Protparam tool were used to predict the possible properties of the peptides.

\subsubsection{Formulation of peptide/pEGFP-N1 nanoparticles}

pEGFP-N1 pEGFP-N1 was complexed by each peptide according to a range of N:P ratios (the molar ratio of positively charged nitrogen atoms in the peptide to negatively charged phosphates in the pEGFP-N1 backbone) via electrostatic interactions. According to the N:P ratio, a quantity of peptide was added to $1 \mu \mathrm{g}$ of pEGFP-N1 in aqueous solution and the final volume was adjusted to $50 \mu 1$ with molecular grade water. The samples were then incubated at room temperature for $30 \mathrm{~min}$ to allow the formation of the nanoparticles. All nanoparticles were used immediately following their preparation unless otherwise stated.

\subsubsection{Size and zeta potential analysis of nanoparticles}

Peptide/pEGFP-N1 complexes were prepared at a range of $\mathrm{N}: \mathrm{P}$ ratios to complex $0.5 \mu \mathrm{g}$ pEGFP-N1 as described in section 2.2.2. A Malvern Zetasizer Nano ZS instrument with DTS software (Malvern Instruments, UK) was used to measure the mean hydrodynamic particle size of nanoparticles by Dynamic Light Scattering (DLS) at $20^{\circ} \mathrm{C}$ followed by measurement of zeta potential by Laser Doppler Velocimetry. 


\subsubsection{Transfection with Peptide nanoparticles delivering pEGFP-N1}

MCF-7 and MDA-MB-231 breast cancer cells were seeded in 96-well tissue culture plates at a density of $2.25 \times 10^{4}$ and $2.5 \times 10^{4}$ cells per well respectively. PC-3 and DU145 prostate cancer cells were seeded at a density of $2.5 \times 10^{4}$ and $2 \times 10^{4}$ cells per well respectively. Cells were allowed to adhere overnight at $37^{\circ} \mathrm{C}$ with $5 \% \mathrm{CO}_{2}$, before being conditioned for $2 \mathrm{~h}$ in serum free OptiMEM (Invitrogen, UK) prior to transfection. $50 \mu 1$ of Peptide/pEGFP-N1 nanoparticles containing $0.5 \mu \mathrm{g}$ pEGFP-N1, prepared as per section 2.2.2, was added to the appropriate wells and cells were incubated with the nanoparticles in OptiMEM for $4 \mathrm{~h}$, before being replaced with complete media. Endosomal escape was assessed by adding $1 \mathrm{mM}$ chloroquine (Sigma-Aldrich, UK) immediately before transfection, giving a final concentration of $10 \mu \mathrm{M}$ chloroquine in the nanoparticle transfection mix.

\subsubsection{Fluorescence microscopy}

To facilitate qualitative analysis of pEGFP-N1 expression correlating to transfection efficiency, cells were visualised and imaged $48 \mathrm{~h}$ following transfection under fluorescent light using an EVOS FL Cell Imaging System (Life Technologies).

\subsubsection{Flow cytometric analysis of transfection efficiency}

Transfected cells were trypsinised and resuspended in $2 \%$ formaldehyde in PBS and kept refrigerated at $4^{\circ} \mathrm{C}$ until analysis. A FACScalibur system (BD Bioscience, UK) was used for the detection of green fluorescent protein (GFP) expressing cells.

\subsubsection{Gel retardation assay}

Peptide/pEGFP-N1 complexes were electrophoresed through a 1\% agarose gel containing ethidium bromide with Tris-acetate (TAE) running buffer at $100 \mathrm{~V}$ for $60 \mathrm{~min}$. Mobility of pEGFP-N1 in the gel was visualised under UV light using a Multispectrum Bioimaging System 
(UVP, UK). Image $\mathrm{J}$ software was used to perform densitometric analysis on gel retardation gel images to quantify fluorescent intensity from each band correlating to amount of pEGFP$\mathrm{N} 1$ in each sample.

\subsubsection{Complexation of pEGFP-N1}

Quant-iT ${ }^{\mathrm{TM}}$ PicoGreen ${ }^{\circledR}$ Reagent (Life Technologies, UK) was diluted 1:200 in TAE buffer and $50 \mu 1$ was added to each sample of Peptide/pEGFP-N1 complexes. Sample fluorescence was analysed by excitation at $480 \mathrm{~nm}$ and the fluorescence emission intensity measured at 520 nm using a FLUOstar Omega Multimode Plate Reader (BMG Labtech, UK).

\subsubsection{Transmission electron microscopy (TEM)}

Peptide/pEGFP-N1 complexes were loaded onto a carbon coated copper 400 mesh grid (TAAB Laboratories, UK) and allowed to dry. Following drying, the samples were stained with UranyLess (EMS Microscopy Academy, USA) at room temperature for 1 min, washed with molecular grade water and allowed to dry again. Nanoparticles were imaged using a JEM-1400Plus Transmission Electron Microscope (Joel, USA) at an accelerating voltage of $120 \mathrm{kV}$.

\subsubsection{Serum stability}

Peptide/pEGFP-N1 complexes were incubated for $1,2,3,4,5$ and $6 \mathrm{~h}$ at $37^{\circ} \mathrm{C}$ in the presence and absence of $10 \%$ foetal calf serum. Subsequently, sodium dodecyl sulfate (SDS) (SigmaAldrich, UK) was added (10\%) to de-complex the particles. Following incubation for $10 \mathrm{~min}$, samples were electrophoresed through a $1 \%$ agarose gel.

\subsubsection{Temperature stability}

Peptide/pEGFP-N1 complexes were prepared and particle size was measured at various temperatures using a Nano ZS Zetasizer with DTS software (Malvern Instruments, UK). 


\subsubsection{Stability over time}

Peptide/pEGFP-N1 complexes were prepared and stored at room temperature for $0,7,14,21$ and 28 days before particle size and zeta potential were measured.

\subsubsection{Endosomal escape and cellular uptake pathway studies}

To investigate cellular entry of Peptide/pEGFP-N1 complexes, cells were pre-treated with either 10 $\mu \mathrm{M}$ Chlorpromazine (Sigma-Aldrich, UK), $200 \mu \mathrm{M}$ Genistein (Sigma-Aldrich, UK), 5 mmol/L methyl$\beta$-cyclodextran (M $\beta C D$ ) (Sigma-Aldrich, UK) or stored at $4^{\circ} \mathrm{C}$ in OptiMEM for $2 \mathrm{~h}$ before transfection.

\subsubsection{Microscopic analysis of intracellular delivery of pEGFP-N1}

pEGFP-N1 was fluorescently labelled with the Cy3 fluorophore (Mirus, USA) according to manufacturer's instructions. MDA-MB-231 were seeded at $4 \times 10^{4}$ per well and then transfected with nanoparticles. $4 \mathrm{~h}$ post transfection, cells were fixed and permeabilised with $4 \%$ formaldehyde and $0.1 \%$ Triton-X (Sigma, UK) for $20 \mathrm{~min}$. Cells were then stained with Fluorescein (FITC)-phalloidin (Life technologies, UK) at room temperature for $15 \mathrm{~min}$ and mounted onto a microscope slide with Fluoroshield mounting medium containing DAPI nuclear stain (Life Technologies, UK). Cells were then imaged using a TSC SP5-Leica Microsystems confocal microscope (Leica, UK) and analysed using LAS AF Lite Software (Leica, UK).

\subsubsection{Cell viability}

Cell viability was evaluated by MTS assay with CellTiter 96 AQueous One Solution Cell Proliferation Assay (Promega, UK). MDA-MB-231 and PC-3 cells were seeded at a density of $1.5 \times 10^{4}$ cells per well and MCF-7 and DU145 cells seeded at $1.2 \times 10^{4}$ cells per well, and allowed to adhere in a 96 well plate. Cells were transfected with peptide/pEGFP-N1 nanoparticles. CellTiter reagent was added to each well $24 \mathrm{~h}$ post transfection to give a final volume of $10 \%$ and returned to the incubator for $2 \mathrm{~h}$. Absorbance was read at $490 \mathrm{~nm}$ using a 
Bio-Tek Powerwave XS plate reader with Gen5 software and any background absorbance was subtracted from readings. Cell viability was expressed as a percentage of the untreated control where the untreated control is considered to be $100 \%$ viable.

\subsubsection{Haemolysis assay}

Ovine whole blood (TCS Biosciences Ltd, UK) was centrifuged at $400 \mathrm{~g}$ for $20 \mathrm{~min}$ to separate erythrocytes. Erythrocytes were washed twice with citrate phosphate buffer at either pH 5.5 or $\mathrm{pH} 7.4$, centrifuged at $400 \mathrm{~g}$ for $20 \mathrm{~min}$, and supernatant discarded. Citrate-phosphate buffer solutions were prepared with $0.1 \mathrm{M}$ citric acid $\left(\mathrm{C}_{6} \mathrm{H}_{8} \mathrm{O}_{7}\right)$ and $0.2 \mathrm{M}$ disodium hydrogen phosphate $\left(\mathrm{Na}_{2} \mathrm{HPO}_{4}\right)$. Erythrocytes were then re-suspended in citrate phosphate buffer solution ( $\mathrm{pH} 5.5$ and $\mathrm{pH} 7.4)$ at a concentration of $1 \times 10^{8}$ cells $/ \mathrm{ml}$. Peptide $2 / \mathrm{pEGFP-N1}$ complexes were prepared at N:P 6, 12 and 20 and added to erythrocyte suspension at each pH, and incubated at $37^{\circ} \mathrm{C}$ for $30 \mathrm{~min}$ under constant shaking at $100 \mathrm{rpm}$. Following incubation, erythrocytes were centrifuged at $400 \mathrm{~g}$ for $5 \mathrm{~min}$, and the supernatant collected. Absorbance of supernatant was measured using a Nanodrop 2000 spectrophotometer (ThermoScientific, USA) at $541 \mathrm{~nm}$. A solution of 1\% Triton X-100 was used as a positive control, representing $100 \%$ haemolysis. Samples treated only with the citrate phosphate buffer at each $\mathrm{pH}$ served as negative controls. Percentage haemolysis was calculated as a percentage relative to the positive control.

\subsubsection{Circular dichroism}

Circular dichroic spectra were recorded on a Jasco J-815 spectropolarimeter (Jasco International Co. Ltd., Japan), temperature controlled via an external circulating water bath. Spectra were recorded at a scan rate of $50 \mathrm{~nm} / \mathrm{min}$ and the signal was averaged over three scans. Molar ellipticities per residue were calculated using the equation: 


$$
[\theta]=\frac{100(\theta)}{(\mathrm{lcN})}
$$

where $[\theta]$ is the molar ellipticity per residue, $(\theta)$ is the observed ellipticity in degrees, 1 is the optical path length in centimeters, $\mathrm{c}$ is the molar concentration of the peptide, and $\mathrm{N}$ is the number of residues in the peptide (Peptide 2 is 22). The $\alpha$-helical content of the samples at various $\mathrm{pHs}$ was determined using the equation:

$$
f_{\mathrm{H}}=\frac{[\theta]_{222}}{[\theta]_{\mathrm{H} \infty}+\mathrm{ik} / \mathrm{N}}
$$

where $f \mathrm{H}$ is the fraction of peptide in a helical conformation, $[\theta] 222$ is the molar ellipticity at $222 \mathrm{~nm}$, and $[\theta] \mathrm{H} \infty$ is the molar ellipticity at $222 \mathrm{~nm}$ for a helix of infinite length $(-39,500 \mathrm{deg}$ $\mathrm{cm} 2 \mathrm{dmol}-1$ ), $\mathrm{i}$ is the number of helical segments per peptide (taken as 1 ), $\mathrm{k}$ is the wavelength dependent constant (2.57 at $222 \mathrm{~nm}$ ) and $\mathrm{N}$ is the number of residues in the peptide (in the case of Peptide 2 this is 22). The spectra were recorded at $20^{\circ} \mathrm{C}$ using a cell of path length $1 \mathrm{~cm}$, and all the samples were prepared in $10 \mathrm{mM} \mathrm{NaH}_{2} \mathrm{PO} 4$ buffer containing $150 \mathrm{mM} \mathrm{NaCl}$.

\subsubsection{Statistical analysis}

Unless otherwise stated, three independent experiments were conducted for analysis of data from the nanoparticle characterisation and the in vitro and in vivo studies. The results are presented as mean \pm SEM $(n=3)$. Statistically significant differences were computed using one-way analysis of variance and a $p$-value of $\leq 0.05$ being considered as significant. Statistical posthoc tests for individual experiments are detailed in figure legends. Statistical analysis was performed using Prism 8.0 (GraphPad Software, CA, USA). 


\section{Results}

\subsection{Peptide Design}

Peptides were designed in pairs to facilitate direct comparison and analysis of functionality, based on specific amino acid sequence differences (Table 1). Each of the peptides designed were predicted to have an amphipathic nature; represented by each helical wheel (Figure 2). In each helical wheel, a clear separation can be found between the hydrophobic leucine residues on one face of the helix and the hydrophilic arginine residues on the other. The hydrophobic moment for each peptide is also shown, which is the highest for Pep1 and Pep2 at 10.95 and 9.73 respectively. The larger the moment, the higher the degree of separation. Maestro 3D structure modelling software enabled visualisation of amino acid placement in each peptide (Figure 3).

\subsection{Initial screening of peptides physicochemical properties}

Each peptide was complexed with pEGFP-N1 and gel retardation assays indicated that the DNA was fully neutralised by all six amphipathic peptides (S1 \& S2). Complexation assays indicated that from N:P 4 with Pep2 and 3, 70\% of the cargo was condensed which increased to $90 \%$ for Pep2 at N:P6 upwards (S3). For Pep1, 4 and 6, a higher N:P ratio of 8 was required to reach $70 \%$ complexation of cargo. Pep5 had the lowest complexation at 50-60\% above N:P 10.

Dynamic Light Scattering revealed that pEGFP-N1 was complexed by each peptide into cationic nanoparticles as summarised in Table 2 (S4 \& S5). A gradual decrease in particle size and increase in zeta potential was observed as N:P ratio increased with Pep2, 3 and 4 . However, Pep1, 5 and 6 did not produce size suitable particles with a positive zeta potential until much higher N:P ratios, with zeta potential just above zero. . 


\subsection{Functionality of novel peptides}

To assess the functional ability of each peptide to deliver pEGFP-N1 cargo to cells, nanoparticles at a range of $\mathrm{N}: \mathrm{P}$ ratios with each peptide were prepared with $\mathrm{pEGFP}-\mathrm{N} 1$ and delivered to MCF-7 and MDA-MB-231 breast cancer cells (S6). Figure 4 shows fluorescence microscope images of each peptide following transfection in both cell lines at N:P 12. Pep1, 2 and 4 indicated successful transfection in both cell lines, but Pep 5 and 6 were not any more efficient than naked DNA in MDA-MB-231, and similarly with Pep3 in both cell lines (S6E). In fact, the only peptide capable of producing transfection efficiencies comparable to RALA (33\% in MCF-7 and 31\% in MDA-MB-231) was Pep2, which at N:P 12 resulted in 31\% and 34\% transfection in MCF-7 and MDA-MB-231 cells respectively (Figure 4C).

MCF-7 Breast cancer cells were transfected with nanoparticles in the presence or absence of chloroquine, a known endosomal disrupter. Higher transfection efficiency in the presence of chloroquine would indicate that the peptides cannot escape the endosome. In MCF-7 MDAMB-231 cells, transfection efficiencies with Pep2, 5 and 6 were not significantly different following the addition of chloroquine (Figure 2 4D), indicating that endosomal entrapment did not impede transfection. Statistically significant increases in transfection were observed following transfection with Pep1, 3 and 4 in the presence of chloroquine $(* \mathrm{P}=<0.05, * * \mathrm{P}=$ $<0.01, * * * \mathrm{P}=<0.001)$ indicating that each of these peptides did not escape the endosome in MCF-7 cells.

The initial screening of the peptides indicated that Pep2 fulfilled criteria with respect to physiochemical characteristics, cellular entry and endosomal escape and transfection. Pep2 was therefore taken forward for further evaluation. 


\subsection{Characterisation and stability of Pep2/pEGFP-N1 Complexes}

The agarose gel indicated charge neutralisation of pEGFP-N1 from N:P ratio 4 upwards, with no migration through the gel. Indeed, with higher N:P ratios pEGFP-N1 is less visible, which is indicative of a tighter condensation as confirmed with the densitometric analysis (Figure 5A \& B). The Picogreen assay indicated complexation of the pEGFP-N1 at 90\% from N:P 6 (Figure 5C). The nature of intercalated electrostatic interaction between peptide and DNA will always have $<10 \%$ nucleic acid detectable even though it is fully complexed in the nanoparticle. TEM revealed the formation of nanoparticles at N:P 12 (Figure 5D) and with a Z-Average of $187.13 \mathrm{~nm}$ and a zeta potential of $+20.07 \mathrm{mV}$ (Figure 6A). Figure 6C also indicates that over $\mathbf{9 8 \%} \mathbf{9 9 \%}$ of the nanoparticle population are nano-sized. The Pep2/pEGFP$\mathrm{N} 1$ nanoparticles were stable over a range of temperatures $\left(4^{\circ} \mathrm{C}-40^{\circ} \mathrm{C}\right)$ and room temperature time course (Figure 6D \& E). A serum stability assay revealed that Pep2 prevented DNA degradation following incubation in 10\% serum for $6 \mathrm{~h}$ (Figure $6 \mathrm{~F}$ ).

\subsection{In Vitro Efficacy of Pep2/pEGFP-N1 nanoparticles}

Pep2/pEGFP-N1 nanoparticles were tested with two prostate cancer cell lines DU145 and PC3. At $\mathrm{N}: \mathrm{P} 10$, the transfection efficiency was $37 \%$ in DU145 and $31 \%$ in PC-3 cells, which is not significantly different from our established delivery peptide RALA efficacies of $33 \%$ and $20 \%$ respectively (Figure 7A \& B). Orthogonal sectioning and confocal microscopy confirmed intracellular and nuclear delivery of Cy3 labelled pEGFP-N1 4 h post-transfection in MDAMB-231 cells (Figure 7C).

Transfections were carried out in MCF-7 and MDA-MB-231 cells pre-treated with various cellular uptake pathway inhibitors including chlorpromazine (inhibitor of clathrin-mediated 
endocytosis), genistein (inhibitor of caveolae mediated inhibition) and $\mathrm{M} \beta \mathrm{CD}$ (cholesterol inhibitor, affecting clathrin and caveolae mediated uptake). At $4^{\circ} \mathrm{C}$ nanoparticles may only enter the cell through direct translocation, since endocytosis, an energy-dependent process, is inhibited at this temperature $[24,25]$. Therefore, cellular uptake was also investigated at $4^{\circ} \mathrm{C}$ to investigate if non-energy-dependent direct internalisation pathways were involved (Figure 7D B). In MCF-7 cells, uptake was significantly reduced with chlorpromazine $(* \mathrm{P}=<0.05)$ and at $4{ }^{\circ} \mathrm{C}(* * * \mathrm{P}=<0.001)$ which indicates that the main mode of entry is via clathrin mediated endocytosis with $16.9 \%$ of the $43 \%$ transfection efficiency attributed to direct translocation. In MDA-MB-231 cells however, reduced transfection was observed with all three inhibitors and significantly reduced at $4^{\circ} \mathrm{C}$ with $14.5 \%$ of the $34 \%$ transfection efficiency attributed to direct translocation $(* \mathrm{P}=<0.05)$.

\subsection{Cell viability and Lytic activity of Pep2/pEGFP-N1 nanoparticles}

The MTS assay revealed that as the N:P ratio increases so does the toxicity in all four cell lines. Over $80 \%$ of MCF-7 cells were viable following treatment with N:P 6 and N:P 10, but this reduced significantly to $50 \%$ viable cells following treatment with N:P 20. In MDA-MB-231 cells $\sim 60 \%$ cells are viable at N:P 6 , which is reduced to $40 \%$ and then $20 \%$ at N:P 10 and N:P 20 respectively (Figure 8A). A similar trend was observed in DU145 and PC-3 cells, where cell viability peaked around $50 \%$ at N:P 6 but then reduced to between $30 \%$ and $40 \%$ at N:P 20, respectively (Figure 8B). In comparison, viability with RALA N:P 6 in both cell lines was over $80 \%$.

Erythrocytes were used to interrogate the lytic activity on cellular membranes of the Pep2 at both physiological $\mathrm{pH}$ of 7.4 and endosomal conditions with a $\mathrm{pH}$ of 5.5. (Figure 8C). In neutral conditions, lysis was $40 \%$ at N:P 6 and increased to $70 \%$ as N:P ratio increased to N:P 20 this 
confirming the toxicity at higher N:P ratios. However, almost $100 \%$ lysis was observed at $\mathrm{pH}$ 5.5 at all three N:P ratios, indicating Pep 2 had a $\mathrm{pH}$ dependant nature.

Circular dichroism was employed to determine if the $\mathrm{pH}$ responsiveness could be attributed to the increased $\alpha$-helical nature of Pep2 (Figure 8D). The spectra of Pep 2 over a range of $\mathrm{pH}$ indicated that the $\alpha$-helical conformation remained at a steady state. The production of double minima at 222 and $207 \mathrm{~nm}$, which is characteristic of an $\alpha$-helix, served to confirm the existence of the peptide in this conformation and that it was not altered by $\mathrm{pH}$.

\section{Discussion}

Six new peptides were designed with the aim of producing a peptide that supersedes RALA in terms of transfection, with as few residues as possible. The combination of cationicity and amphipathicity leads to strong transfection efficiency with RALA and these characteristics were considered extremely important when designing novel peptides.

Each pair of peptides were predicted to have a similar theoretical charge (computed using the Protparam bioinformatics tool), however the N:P ratio at which pEGFP-N1 was neutralised suggested that peptide sequence and folding are key factors (S1 and S2). Pep1 with 3 tryptophan residues did not fully neutralise the DNA until N:P 8, but Pep2 with 2 tryptophan residues resulted in full neutralisation at $\mathrm{N}: \mathrm{P}$ 4. When cationicity increases, electrostatic attraction between the anionic and cationic species overcomes the pEGFP-N1 bending stress penalty, and the semi-flexible pEGFP-N1 molecule is wrapped with the cationic particles $[26,27]$. Conformational behaviour is impacted by the geometry of interacting species, therefore the bulky aromatic side chain of tryptophan residues may spatially hinder the interactions between cationic arginine residues and pEGFP-N1. Pep3 also required a higher 
$\mathrm{N}: \mathrm{P}$ ratio of 10 compared to Pep4 at N:P 4 to neutralise the DNA. Pep4 with the extra arginine residue has a stronger cationicity, enabling more efficient DNA binding. However, if the spacing of $\operatorname{Trp}(\mathrm{W}) \rightarrow \operatorname{Arg}(\mathrm{R})$ is ordered $(\mathrm{i}, \mathrm{i}+4)$ there is a favourable contribution of free energy to aid helix stability [28]. The sequence (WXXXR) where a tryptophan is at position one and arginine at position five, with any amino acid in between, causes the tryptophan and arginine to be adjacent in the spatial arrangement of the helix. This adjacent arrangement is optimal for cationic- $\pi$ interactions. In Pep5 the sequence is incorporated once (W1 and R5), and twice in Pep6 (W1 - R5 and W4 - R8). The double inclusion of this sequence in Pep6 may explain the enhanced condensation of DNA compared to Pep5. Complexation was also improved with Pep6 compared to Pep5, and the results concur with the WXXXR theory that $\mathrm{W}$ can be present, but that the ordering of other cationic amino acids is critical for efficient cargo interactions.

However, Pep5, 6, 1 and 3 had sub-optimal nanoparticle formation with respect to size, charge and homogeneity. DLS analysis corroborated the gel electrophoresis and complexation assays with variable results between peptide pairs. In most cases, a high $\mathrm{N}: \mathrm{P}$ ratio was required to achieve production of size suitable $(<200 \mathbf{n m})$ cationic nanoparticles (Table 2 , S4). This is very different to the activity of RALA, which forms stable, homodisperse nanoparticles at $\mathbf{N}: P$ ratios above 4 [6]. All peptides, with the exception of Pep2, produced much lower zeta potential values $(\sim 10-20 \mathrm{mV})$ than that of RALA $(+30 \mathrm{mV})$. This decrease in zeta potential may be attributed to the reduction in the number of cationic arginine residues and increase in hydrophobic nature of the truncated peptides. High PDI values $>0.6$ with Pep1, 3, 5 and 6 also indicated poor nanoparticle formulation, with only Pep2 and Pep4 producing more homodisperse nanoparticle populations (S5). 
The inclusion of the tryptophan residues in the truncated sequence of Pep2 may have enhanced interaction with the cell membranes, via anchoring of the aromatic side chain into the lipid bilayer of cell membranes [29]. Rydberg et al used fluorescently labelled peptides containing eight arginine and a range of one to four tryptophan residues to demonstrate that cellular uptake increases with a higher number of tryptophan residues [30]. Pep2 contains two tryptophan residues, when compared with Pep1 which has three tryptophan residues. It has been reported that strong interactions between tryptophan and the lipid membrane might lead to less efficient internalisation, if the peptide becomes inserted too deeply into the lipid membrane [31]; which may explain the difference in transfection between Pep1 and Pep2. It is possible that an optimal balance of tryptophan is required to allow efficient cellular uptake, but that the charge is the overriding factor in terms of nanoparticle stability.

The transfection efficiency in both cell lines with Pep3, 4, 5 and 6 was significantly lower than that of RALA. Each of these peptides have a much-truncated sequence compared to RALA, despite having the minimum number of six arginine residues [18]. However, the position of the arginine residues is also integral. The 3D structure of RALA (Figure 1) demonstrates how the side chains of hydrophilic arginine and hydrophobic leucine curve around the helix along the length of the peptide chain. This enables RALA to 'corkscrew' through the cell membrane. In addition to peptide sequence, the properties of the particles formed will influence interaction with cell membranes. The poor uniformity of particles produced with Pep1, 3, 5 and 6, evidenced in the DLS analysis, will have had an impact on the transfection efficiency. Particle size is very important for cellular uptake and a size $<200 \mathbf{n m}$ is cited as optimal for endocytosis [32]. Homodispersity is also an important parameter, as nanoparticles within a desired size range are a prerequisite for cellular uptake. Endocytic 
routes are generally size dependent and the presence of large particles or aggregates may reduce transfection efficiency.

The endosomal escape studies indicate that, to some degree, the peptides do cross the cell membrane, but for most, endosomal entrapment does occur. Previously it has been shown that the transfection efficiency of RALA is unaffected by the addition of chloroquine [6]. Activity of fusogenic peptides has been correlated to $\alpha$-helical structure and the protonation of the glutamic acid residues in the sequence [22]. Pep3 and Pep4 were designed with a focus on endosomal escape and the inclusion of glutamic acid residues, but Pep1, 3 and 4 did not escape the endosome. It is possible that the short length of the peptide (20-mer) may cause structural rigidity limiting the possibility of $\mathrm{pH}$ dependent conformational changes. Transfection with Pep2 was unaffected by the addition of chloroquine in both cell lines, indicating that glutamic acid is not required for this peptide and it is the alpha-helical conformation that results in endosomal fusogenic activity.

Pep2 produced nanoparticles with similar characteristics to RALA, which was confirmed by DLS and TEM analysis. Pep2/DNA nanoparticles were stable over time and temperature and transfected other cell lines, with evidence of nuclear delivery of cargo. Clathrin-mediated endocytosis was indicated as the main pathway of internalisation in MCF-7 cells, with evidence of more than one uptake mechanism of internalisation involved in MDA-MB231 cells (Figure 7D). This endocytosis uptake profile is similar to that of RALA, which was found to utilise both caveolae and clathrin-mediated endocytosis, and is in keeping with previous studies highlighting endocytosis as the predominant cell entry pathway for peptides carrying macromolecular cargo $[6,32]$. 
However, cell viability was significantly decreased as the N:P ratio of Pep2 increased, with moderate to strong toxicity at higher $\mathrm{N}: \mathrm{P}$ ratios in all cell lines tested. A high positive charge has been shown to cause toxicity, especially those containing high numbers of arginine residues [18]. However, the charge of the Pep2/DNA nanoparticles was similar to that of the RALA/DNA nanoparticles which have never demonstrated toxicity [6]. The haemolysis assay confirmed the lytic activity of Pep 2 with $100 \%$ lysis of erythrocytes at $\mathrm{pH} 5.5$ which is desirable for endosomal escape, yet at a neutral $\mathrm{pH}$ lysis was $40 \%$ at $\mathrm{N}: \mathrm{P} 6$ and increased to $70 \%$ at $\mathrm{N}: \mathrm{P} 20$. In contrast, the \% lytic activity with RALA was less than $7 \%$ across all N:P ratios (REF). This is critical as it is undesirable for a gene delivery system to cause any lysis in physiological conditions and is a rate-limiting factor for progression. Hydrophobic moment has been linked to toxicity, and the 3x increased moment of Pep2 compared to RALA could be the reason for the toxicity. Hallbrink et al reported that while a higher hydrophobic moment increased cell penetration, it also caused increased membrane leakage as a result of irreversible pore formation [33]. Chen et al also reported that amphipathic peptides with a concentrated charge distribution caused lysis in HeLa cells, while peptides with disperse charge distribution did not exhibit lytic activity [34]. The distribution of the cationic arginine residues is more concentrated in Pep2 than that of RALA, which is equipped with many spacer alanine residues.

\section{Conclusion}

Despite impressive transfection efficiency with Pep2, the progression of this peptide is limited by the toxic effects observed. However, lessons may be learned for future design of amphipathic peptides. In this study we highlight the importance of amino acid placement and sequence length for structural functionality. Tryptophan and arginine residues remain desirable candidates for CPP design, but care with charge distribution is also required to avoid toxicity. 
With further rational design and optimisation, it may be possible to improve the safety profile of Pep2 surrogates to enable progression as a non-viral delivery system.

\section{References}

1. Morille M, Passirani C, Vonarbourg A, Clavreul A, Benoit J-P. Progress in developing cationic vectors for non-viral systemic gene therapy against cancer. Biomaterials. 2008;29(24-25):3477-96.

2. Templeton NS. Cationic liposome-mediated gene delivery in vivo. Biosci Rep. 2002;22(2):283-95.

3. Wilson JM. Lessons learned from the gene therapy trial for ornithine transcarbamylase deficiency. Mol Genet Metab. 2009;96(4):151-7.

4. Wang T, Upponi JR, Torchilin VP. Design of multifunctional non-viral gene vectors to overcome physiological barriers: dilemmas and strategies. Int J Pharm. 2012;427(1):3-20.

5. Hatefi A, Megeed Z, Ghandehari H. Recombinant polymer-protein fusion: a promising approach towards efficient and targeted gene delivery. J Gene Med. 2006;8(4):468-76.

6. McCarthy HO, McCaffrey J, McCrudden CM, Zholobenko A, Ali AA, McBride JW, et al. Development and characterization of self-assembling nanoparticles using a bio-inspired amphipathic peptide for gene delivery. J Control Release. 2014;189:141-9.

7. Bennett R, Yakkundi A, McKeen H, McClements L, McKeogh T, Arthur K, et al. RALA-mediated delivery of FKBPL nucleic acid therapeutics. Nanomedicine. 2015;10(19):2989-3001.

8. Ali AA, McCrudden CM, McCaffrey J, McBride JW, Cole G, Dunne NJ, et al. DNA vaccination for cervical cancer; a novel technology platform of RALA mediated gene delivery via polymeric microneedles. Nanomedicine. 2016;13:921-32.

9. McCrudden CM, McBride JW, McCaffrey J, Ali AA, Dunne NJ, Kett VL, et al. Systemic RALA/iNOS Nanoparticles: A Potent Gene Therapy for Metastatic Breast Cancer Coupled as a Biomarker of Treatment. Mol Ther - Nucleic Acids. 2017;6:249-58.

10. Chang M, Huang Y-W, Aronstam R, Lee H-J. Cellular Delivery of Noncovalently-Associated Macromolecules by Cell- Penetrating Peptides. Curr Pharm Biotechnol. 2014;15(3):267-75.

11. Nakase I, Takeuchi T, Tanaka G, Futaki S. Methodological and cellular aspects that govern the internalization mechanisms of arginine-rich cell-penetrating peptides. Adv Drug Deliv Rev. 2008;60(4-5):598-607.

12. Futaki S, Nakase I, Tadokoro A, Takeuchi T, Jones a T. Arginine-rich peptides and their internalization mechanisms. Biochem Soc Trans. 2007;35:784-7.

13. Ohmori N, Niidome T, Kiyota T, Lee S, Sugihara G, Wada A, et al. Importance of Hydrophobic Region in Amphiphilic Structures of $\alpha$-Helical Peptides for Their Gene Transfer-Ability into Cells. Biochem Biophys Res Commun. 1998;245:259-65.

14. Schmidt N, Mishra A, Lai GH, Wong GCL. Arginine-rich cell-penetrating peptides. FEBS Lett. 2010;584(9):1806-13.

15. Tchoumi Neree A, Nguyen PT, Chatenet D, Fournier A, Bourgault S. Secondary conformational 
conversion is involved in glycosaminoglycans-mediated cellular uptake of the cationic cellpenetrating peptide PACAP. FEBS Lett. 2014;588(24):4590-6.

16. Varkouhi AK, Scholte M, Storm G, Haisma HJ. Endosomal escape pathways for delivery of biologicals. J Control Release. 2011;151(3):220-8.

17. Wender PA, Mitchell DJ, Pattabiraman K, Pelkey ET, Steinman L, Rothbard JB. The design, synthesis, and evaluation of molecules that enable or enhance cellular uptake: peptoid molecular transporters. Proc Natl Acad Sci USA. 2000;97(24):13003-8.

18. Mitchell DJ, Kim DT, Steinman L, Fathman CG, Rothbard JB. Polyarginine enters cells more efficiently than other polycationic homopolymers. J Pept Res. 2000;56:318-25.

19. Kurzawa L, Pellerano M, Morris MC. PEP and CADY-mediated delivery of fluorescent peptides and proteins into living cells. Biochim Biophys Acta. 2010;1798(12):2274-85.

20. Rittner K, Benavente A, Bompard-Sorlet A, Heitz F, Divita G, Brasseur R, et al. New basic membrane-destabilizing peptides for plasmid-based gene delivery in vitro and in vivo. Mol Ther. 2002;5(2):104-14.

21. Crombez L, Aldrian-Herrada G, Konate K, Nguyen QN, McMaster GK, Brasseur R, et al. A new potent secondary amphipathic cell-penetrating peptide for siRNA delivery into mammalian cells. Mol Ther. 2009;17(1):95-103.

22. Erazo-Oliveras A, Muthukrishnan N, Baker R, Wang T, Pellois J. Improving the endosomal escape of cell-penetrating peptides and their cargos: Strategies and Challenges. Pharmaceuticals. 2012;5:1177-209.

23. Jafari M, Karunaratne DN, Sweeting CM, Chen P. Modification of a Designed Amphipathic CellPenetrating Peptide and Its Effect on Solubility, Secondary Structure, and Uptake Efficiency. Biochemistry. 2013;52:3428-35.

24. Walrant A, Correia I, Jiao C-Y, Lequin O, Bent EH, Goasdoué N, et al. Different membrane behaviour and cellular uptake of three basic arginine-rich peptides. Biochim Biophys Acta. 2011;1808(1):382-93.

25. Brock R. The uptake of arginine-rich cell-penetrating peptides: putting the puzzle together. Bioconjug Chem. 2014;25(5):863-8.

26. Zinchenko A. DNA conformational behavior and compaction in biomimetic systems: Toward better understanding of DNA packaging in cell. Adv Colloid Interface Sci. 2016;232:70-9.

27. Zinchenko AA, Sakaue T, Araki S, Yoshikawa K, Baigl D. Single-chain compaction of long duplex DNA by cationic nanoparticles: Modes of interaction and comparison with chromatin. J Phys Chem B. 2007;111(11):3019-31.

28. Shi Z, Olson CA, Kallenbach NR. Cation- $\pi$ Interaction in Model $\alpha$-Helical Peptides. J Am Chem Soc. 2002;124(37):3284-91.

29. Jobin M-L, Blanchet M, Henry S, Chaignepain S, Manigand C, Castano S, et al. The role of tryptophans on the cellular uptake and membrane interaction of arginine-rich cell penetrating peptides. Biochim Biophys Acta. 2015;1848(2):593-602.

30. Rydberg HA, Matson M, Åmand HL, Esbjo EK, Norde B. Effects of Tryptophan Content and Backbone Spacing on the Uptake Efficiency of Cell-Penetrating Peptides. Biochemistry. 2012;51:5531-9. 
31. Bechara C, Sagan S. Cell-penetrating peptides: 20 years later, where do we stand? FEBS Lett. 2013;587(12):1693-702.

32. El-Sayed A, Harashima H. Endocytosis of gene delivery vectors: from clathrin-dependent to lipid raft-mediated endocytosis. Mol Ther. 2013;21(6):1118-30.

33. Hällbrink M, Florén A, Elmquist A, Pooga M, Bartfai T, Langel Ü. Cargo delivery kinetics of cellpenetrating peptides. Biochim Biophys Acta - Biomembr. 2001;1515(2):101-9.

34. Chen L, Zhang Q, Yuan X, Cao Y, Yuan Y, Yin H, et al. How charge distribution influences the function of membrane-active peptides: Lytic or cell-penetrating? Int J Biochem Cell Biol. $2017 ; 83: 71-5$ 
Table 1: Summary of novel peptide pairing to allow comparison of sequences and design rationale.

\begin{tabular}{|c|c|c|c|}
\hline $\begin{array}{l}\text { Peptide } \\
\text { pair }\end{array}$ & Sequence comparison & $\begin{array}{l}\text { Molecular } \\
\text { Weight } \\
\text { (Da) }\end{array}$ & Rationale \\
\hline $\begin{array}{l}1 \\
\text { (22-mer) }\end{array}$ & WARLARAWARAWARLLRRLLAL & 2690.2 & \multirow{2}{*}{$\begin{array}{l}\text { What is the optimal } \\
\text { number of tryptophan } \\
\text { residues for interaction } \\
\text { with cell membrane and } \\
\text { cell uptake? }\end{array}$} \\
\hline $\begin{array}{l}2 \\
\text { (22-mer) }\end{array}$ & WARLARAWARALARLLRRLLAL & 2617.2 & \\
\hline $\begin{array}{l}3 \\
\text { (20-mer) }\end{array}$ & WERLARALLARALARLLARAR & 2333.8 & \multirow{2}{*}{$\begin{array}{l}\text { Will the additional } \\
\text { arginine residue in } \\
\text { Peptide } 4 \text { for improved } \\
\text { transfection efficiency? } \\
\text { Will inclusion of glutamic } \\
\text { acid enhance endosomal } \\
\text { escape? }\end{array}$} \\
\hline $\begin{array}{l}4 \\
\text { (20-mer) }\end{array}$ & WERLARRLARALARLLARAR & 2418.9 & \\
\hline $\begin{array}{l}5 \\
\text { (16-mer) }\end{array}$ & WRLARLLRRLLRALRA & 2033.5 & \multirow{2}{*}{$\begin{array}{l}\text { Extremely truncated } \\
\text { sequence. } \\
\text { Increased interactions } \\
\text { between tryptophan and } \\
\text { arginine to stabilise } \\
\text { nanoparticles? }\end{array}$} \\
\hline $\begin{array}{l}6 \\
\text { (16-mer) }\end{array}$ & WRLWRLLRRLARALRA & 2106.6 & \\
\hline
\end{tabular}


Table 2: Summary of nanoparticle characteristics with each novel peptide following DLS analysis using a Malvern Zetasizer Nano ZS ( $n=3+/-S E M)$.

\begin{tabular}{|c|c|c|c|c|c|c|c|}
\hline \multirow{2}{*}{ Peptide } & \multirow{2}{*}{$\mathrm{N}: \mathrm{P}$ ratio } & \multicolumn{2}{|c|}{ Size $(\mathrm{nm})$} & \multicolumn{2}{|c|}{ Zeta potential (mV) } & \multirow{2}{*}{ PDI } & \multirow{2}{*}{$\begin{array}{l}\text { Kilocounts } \\
\text { per second } \\
\text { (KCPS) }\end{array}$} \\
\hline & & Mean & SD & Mean & $S D$ & & \\
\hline 1 & $\mathrm{~N}: \mathrm{P} 12$ & 102.03 & 55.18 & 11.57 & 5.30 & 0.59 & 281.97 \\
\hline 2 & $\mathrm{~N}: \mathrm{P} 10$ & 187.13 & 21.43 & 20.07 & 2.20 & 0.44 & 272.20 \\
\hline 3 & $\mathrm{~N}: \mathrm{P} 12$ & 203.63 & 79.42 & 6.07 & 4.08 & 0.77 & 171.60 \\
\hline 4 & $\mathrm{~N}: \mathrm{P} 12$ & 150.02 & 73.58 & 14.50 & 0.56 & 0.51 & 198.40 \\
\hline 5 & $\mathrm{~N}: \mathrm{P} 15$ & 114.03 & 53.56 & 3.76 & 3.93 & 0.52 & 203.30 \\
\hline 6 & $\mathrm{~N}: \mathrm{P} 12$ & 57.12 & 6.68 & 11.08 & 5.20 & 0.70 & 167.10 \\
\hline
\end{tabular}




\section{A}
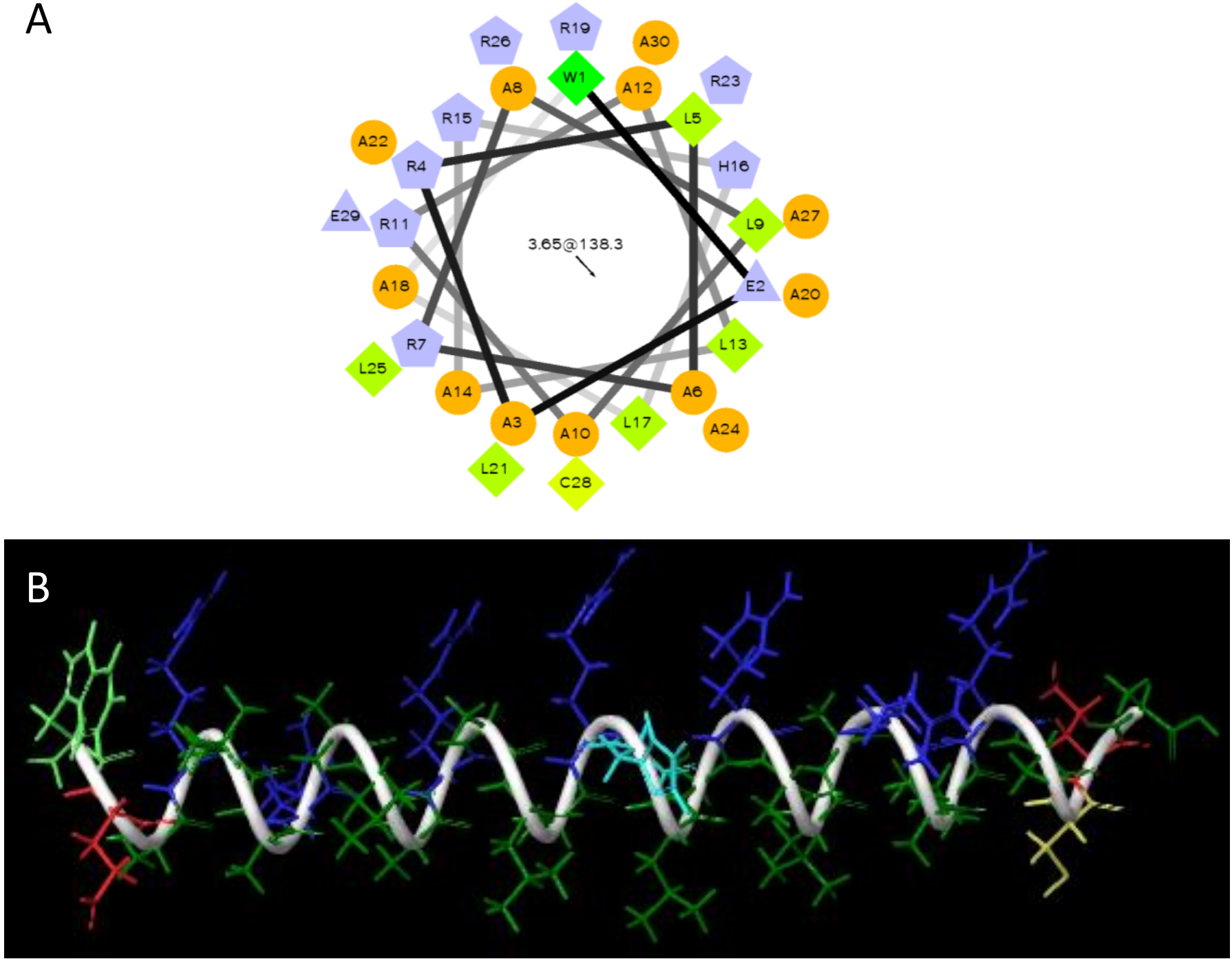

Figure 1: Representation of RALA. A) Helical wheel representation of RALA generated using Helical Wheel projection software from RZ lab (University of California - Riverside). Hydrophilic residues are displayed as circles, hydrophobic residues as diamonds, potentially negatively charged as triangles, and potentially positively charged as pentagons. The most hydrophobic residues are green, and the amount of green is decreases proportionally to the hydrophobicity, with zero hydrophobicity coded as yellow. Potentially charged residues are light blue. The hydrophobic moment is also shown with the arrow indicating the most hydrophobic point in the helix. B) Computed 3D alpha helical structure of RALA generated using Maestro software (Schrodinger). Amino acid key: yellow: cysteine, blue: arginine, green: hydrophobic residues (tryptophan and leucine), turquoise: histidine, red: glutamic acid. 
A

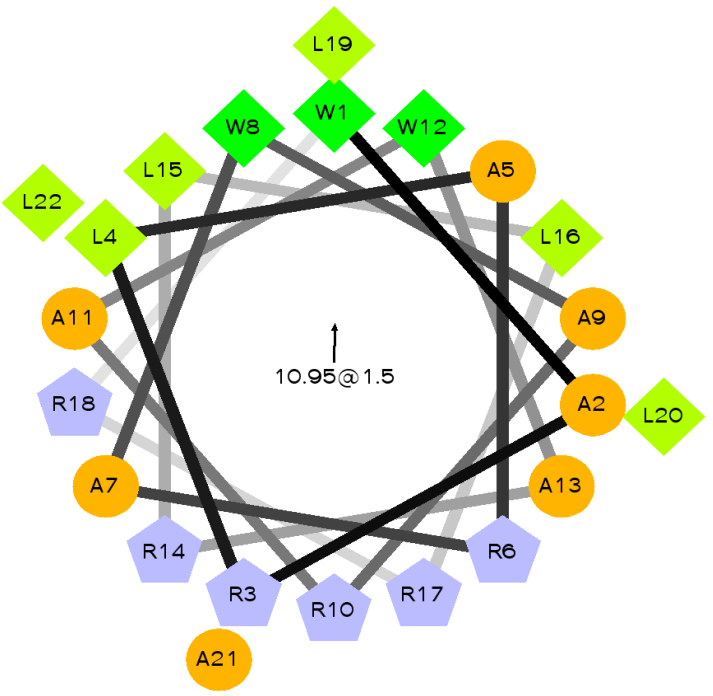

C

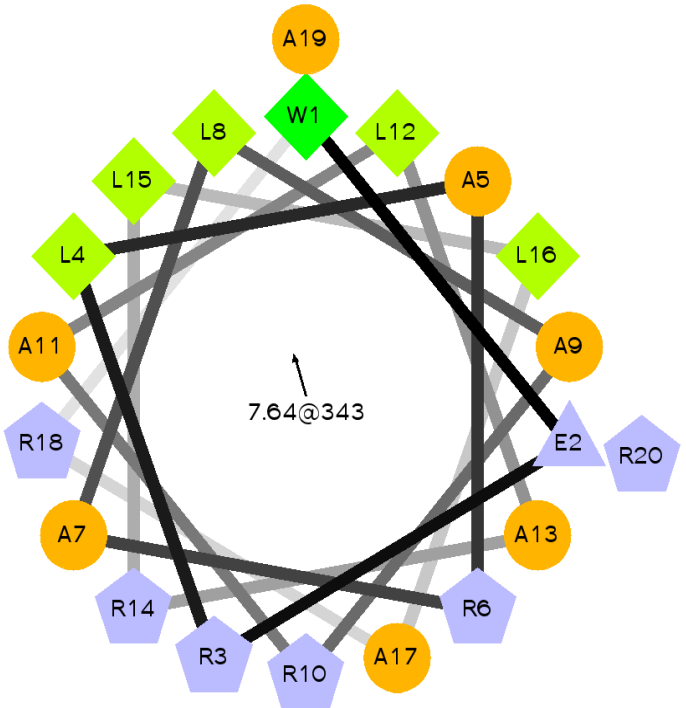

$E$

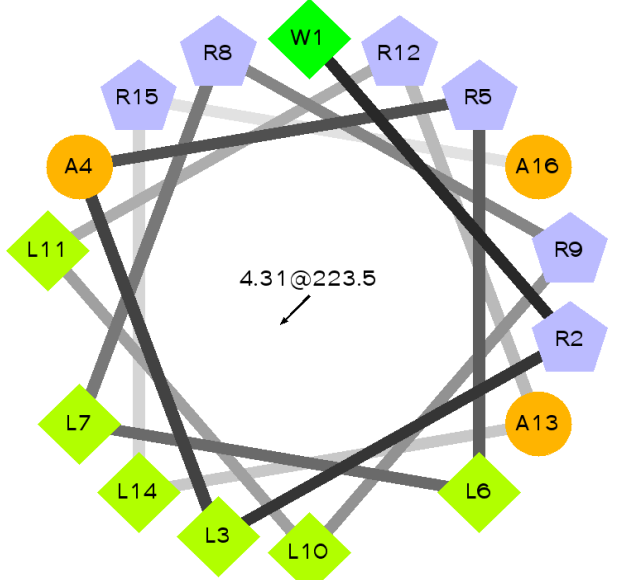

B
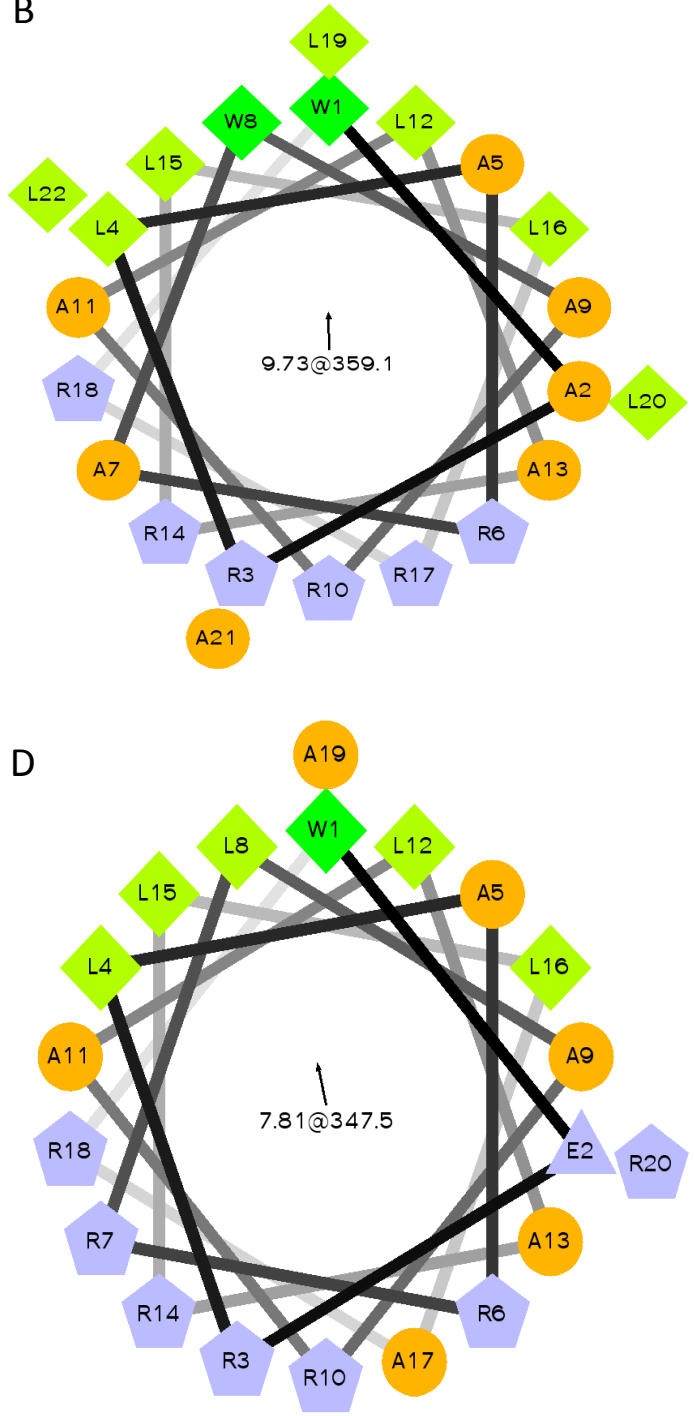

$\mathrm{F}$

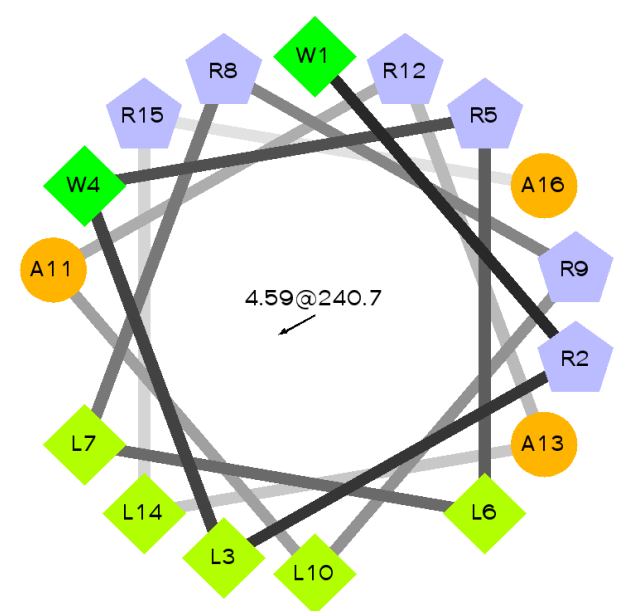

Figure 2: Helical wheel representation of A) Pep1, B) Pep2, C) Pep3, D) Pep4, E) Pep5 and D) Pep6 produced using Helical wheel projection software from RZ Lab, University of California (Riverside). The hydrophobic moment is also shown with the arrow indicating the most hydrophobic point in the helix. Note that Pep1 contains a tryptophan at position 12, whereas Pep2 contains a leucine, Pep3 contains an alanine at position 7, whereas Pep4 contains an arginine and Pep5 contains an alanine at position 4, whereas Pep6 contains a tryptophan. 

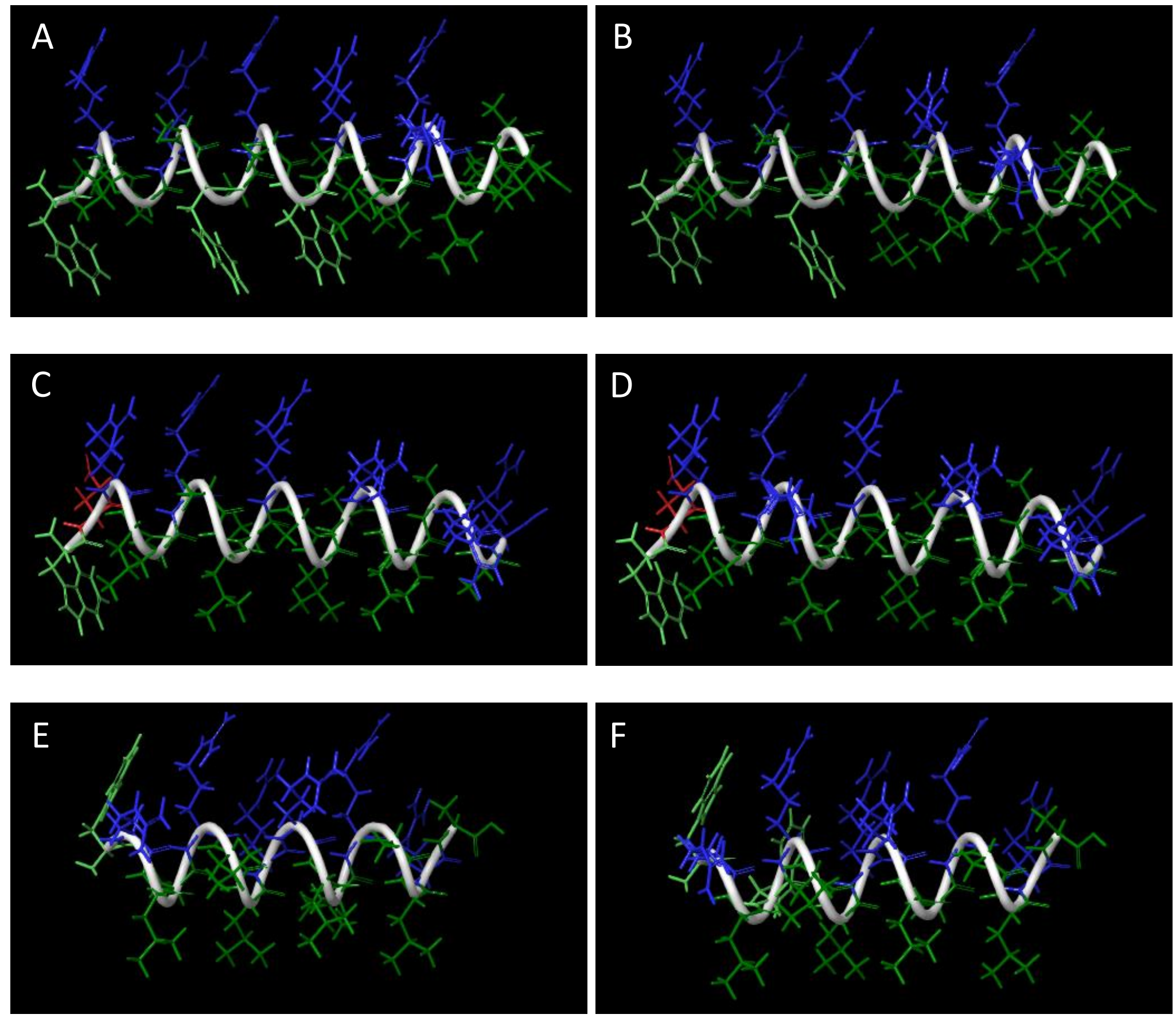

Figure 3: Predicted 3D structure of A) Pep1, B) Pep2, C) Pep3, B) Pep4, E) Pep5 and F) Pep6 computed using Maestro software (Schrodinger). The software models the predicted 3D structure of each peptide in an alpha helix. Amino acid key: blue: arginine, green: hydrophobic residues (tryptophan and leucine), red: glutamic acid. 
A

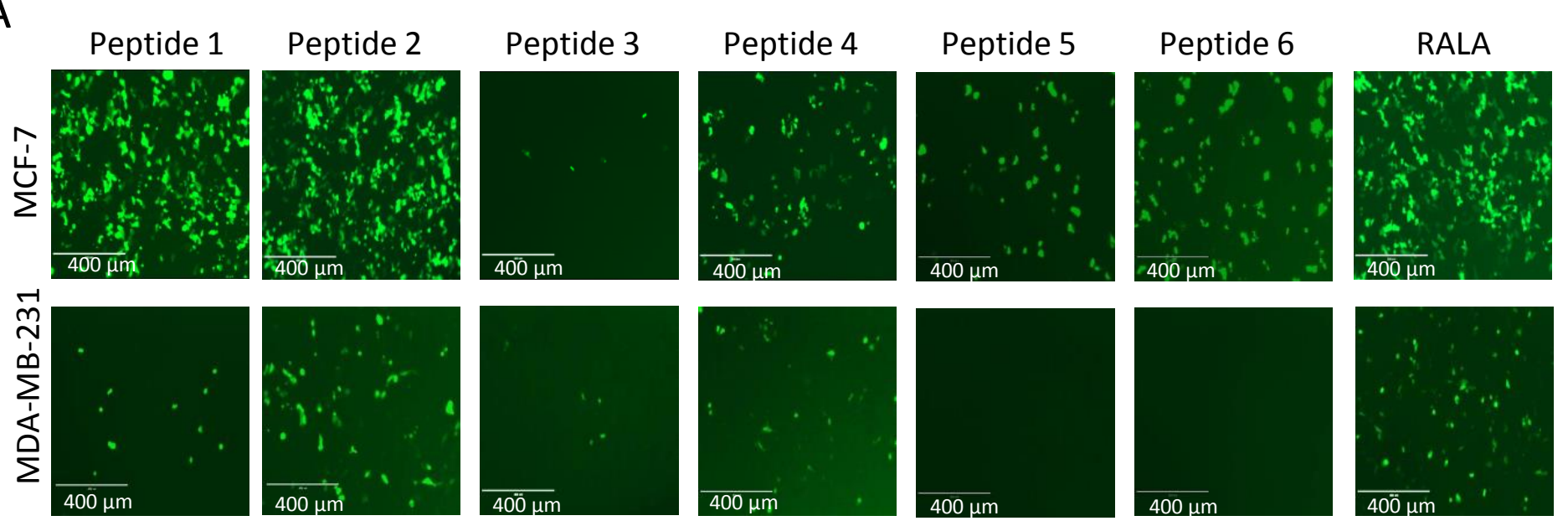

B

\begin{tabular}{ccccccccc}
\hline Cells/MFI & Cells & Pep 1 & Pep 2 & Pep 3 & Pep 4 & Pep 5 & Pep 6 & RALA \\
\hline MCF-7 & 39 & 411 & 425 & 58 & 277 & 191 & 220 & 810 \\
\hline MDA-MB-231 & 15 & 248 & 250 & 63 & 70 & 12 & 15 & 221 \\
\hline
\end{tabular}

C

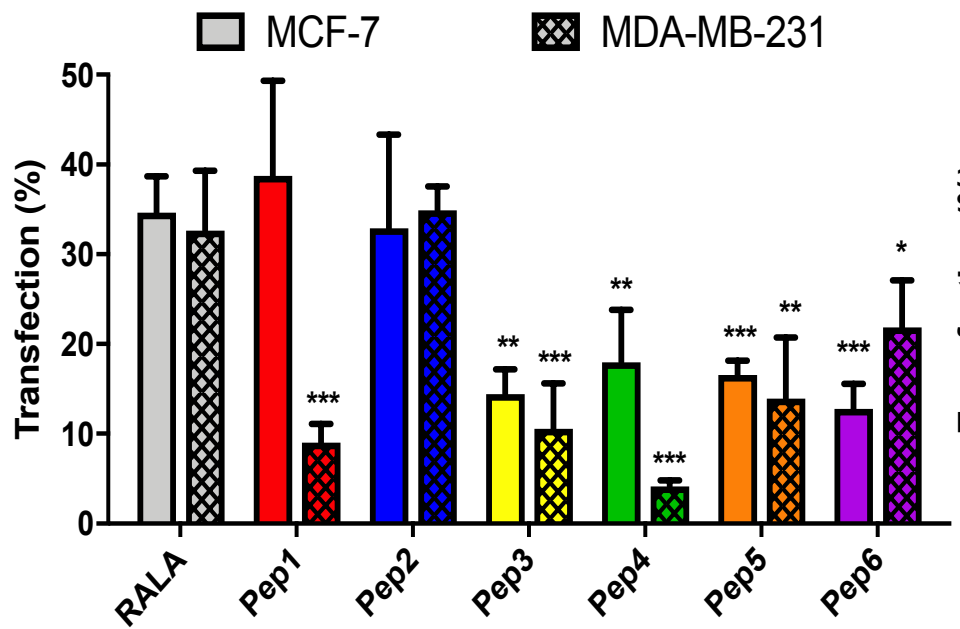

D

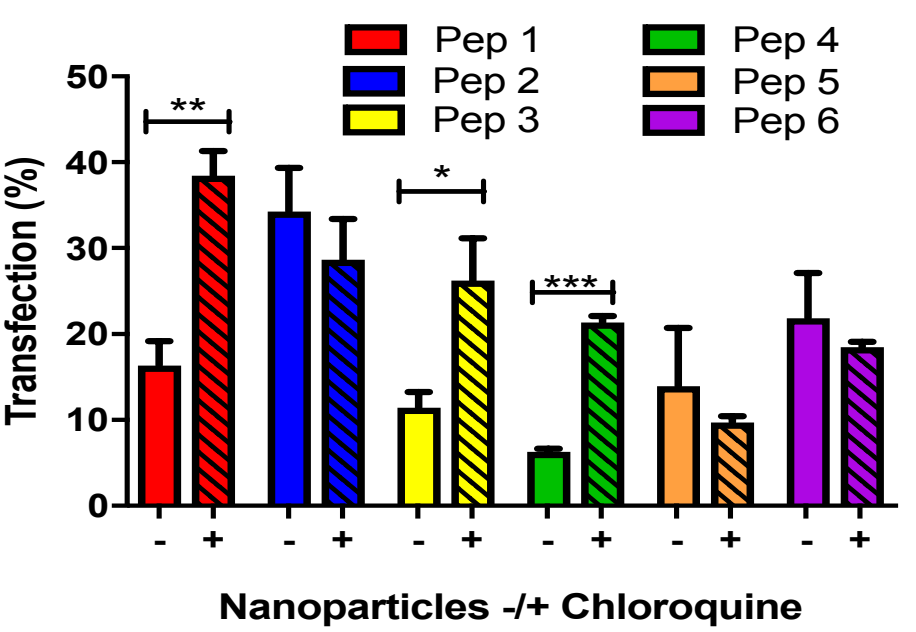

Figure 4: In vitro functionality of novel amphipathic peptides in MCF-7 and MDA-MB-231 breast cancer cells. Cells were transfected for $4 \mathrm{~h}$ with peptide/pEGFP-N1 nanoparticles at N:P ratios 12 or RALA and incubated for a further $48 \mathrm{~h}$ before analyses. A) Fluorescent microscopy images captured with and EVOS FL Cell Imaging System to visualise the expression of the GFP (Scale bar = $400 \mu \mathrm{m})$. B) Mean Fluorescence Intensity (MFI) value of GFP in each sample analysed with flow cytometry using a BD FACS Calibur. C) Quantification of transfection efficiency analysed by flow cytometry ( \pm SEM, $n=3)$. D) Quantification of transfection efficiency in MDA-MB-231 breast cancer cells in the presence or absence of endosomal escape agent chloroquine $(10 \mu \mathrm{M})$ analysed by flow cytometry ( \pm SEM, $n=3$ ). Statistical analysis was carried out by One-Way ANOVA and Dunnett posttest $\left({ }^{*}=\mathrm{P}<0.05,{ }^{* *}=\mathrm{P}<0.01,{ }^{* * *}=\mathrm{P}<0.001\right)$. 
A
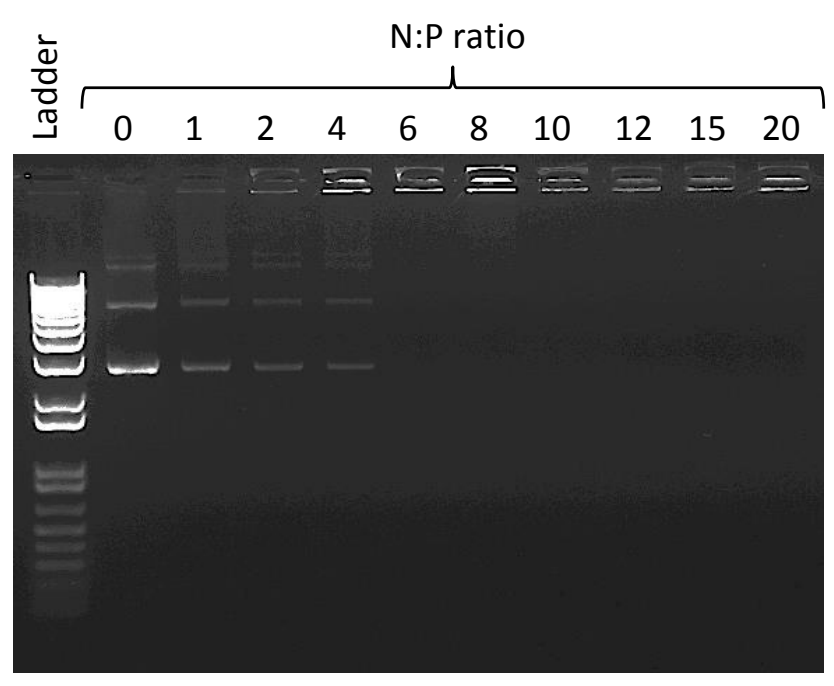

C

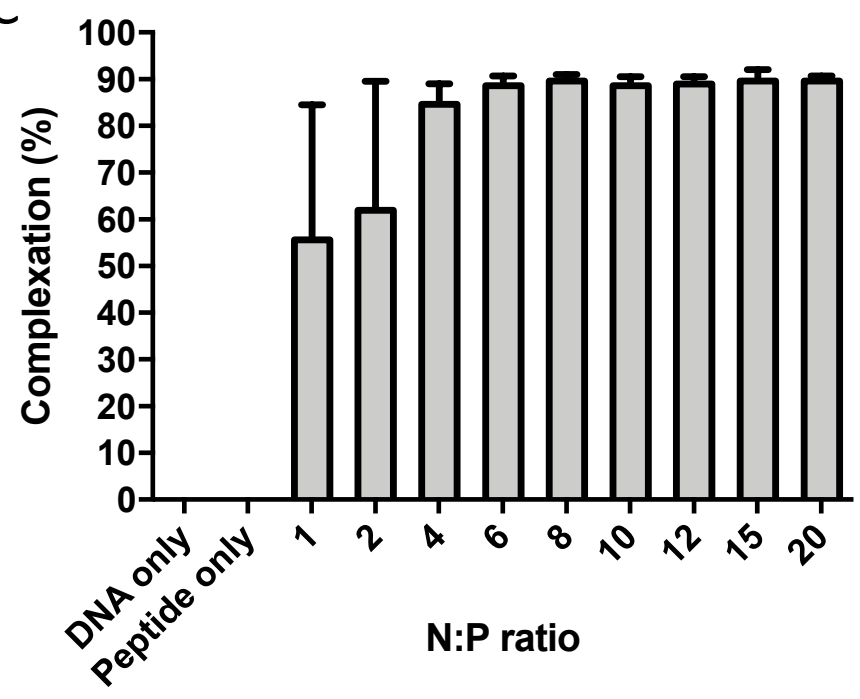

B
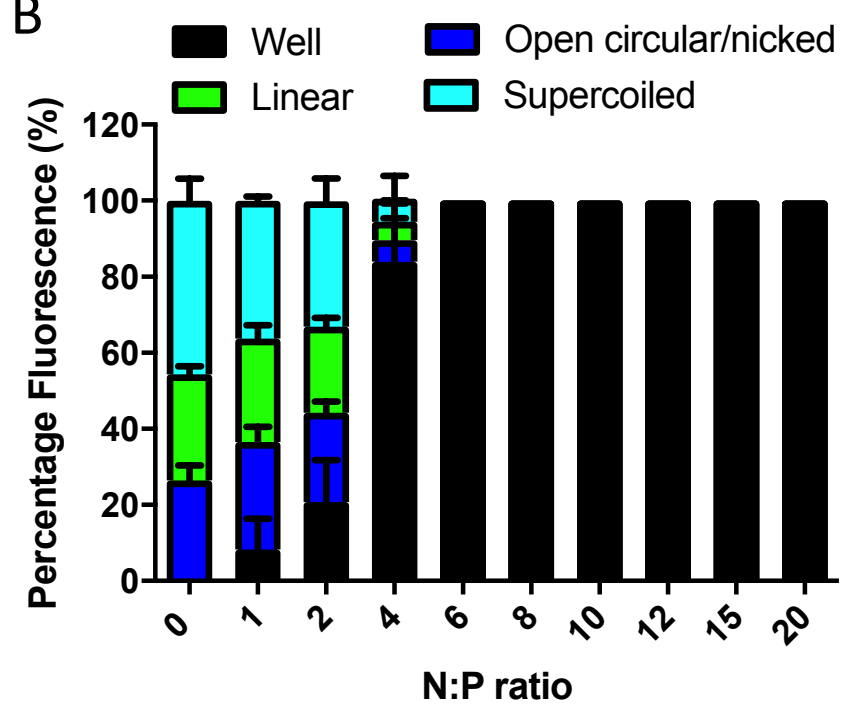

D

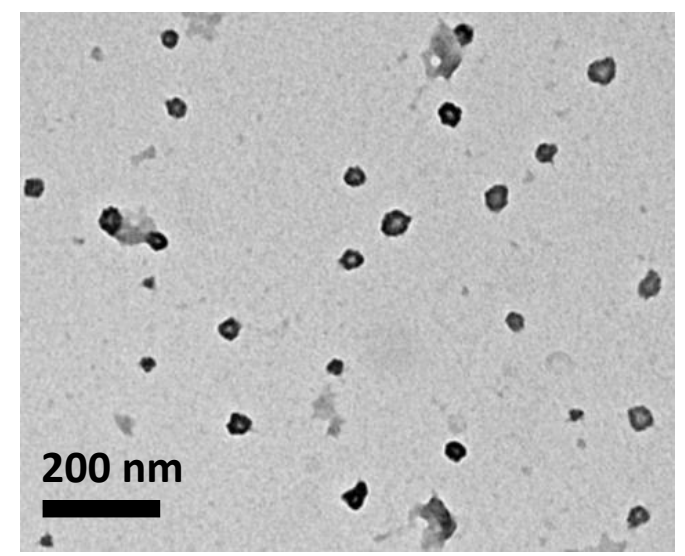

Figure 5: Physicochemical characteristics of Peptide 2. A) Agarose gel electrophoresis indicating mobility of pEGFP-N1 when combined at different N:P ratios with Peptide 2. B) Densitometry of relative fluorescence detected in the agarose gel with respect to characteristic DNA conformation bands (i.e. supercoiled, open circular/nicked or linear conformation) ( $n=3, \pm S E M)$. C) DNA complexation efficiency assay using Quant-iT ${ }^{\mathrm{TM}}$ PicoGreen ${ }^{\circledR}$ Reagent indicating the efficiency of Peptide 2 to complex DNA at a range of $N: P$ ratios $(n=3, \pm S E M)$. D) Image of Pep2/pDNA complexes at N:P 12 taken using transmission electron microscopy (T.E.M.) at $40 \mathrm{k}$ magnification (Scale bar $=200 \mathrm{~nm}$ ). 
A

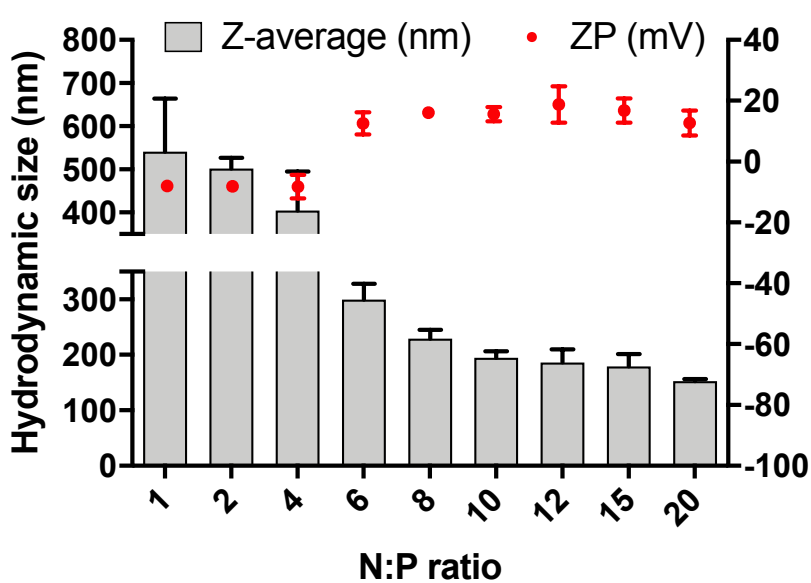

C
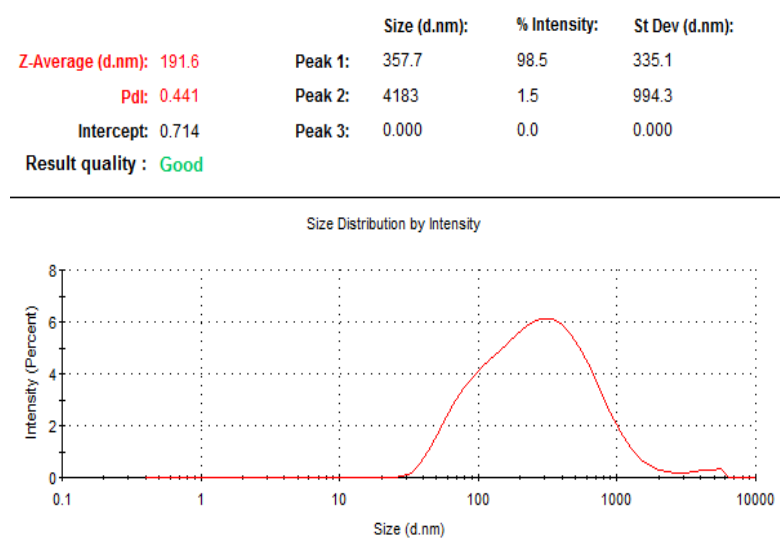

$E$

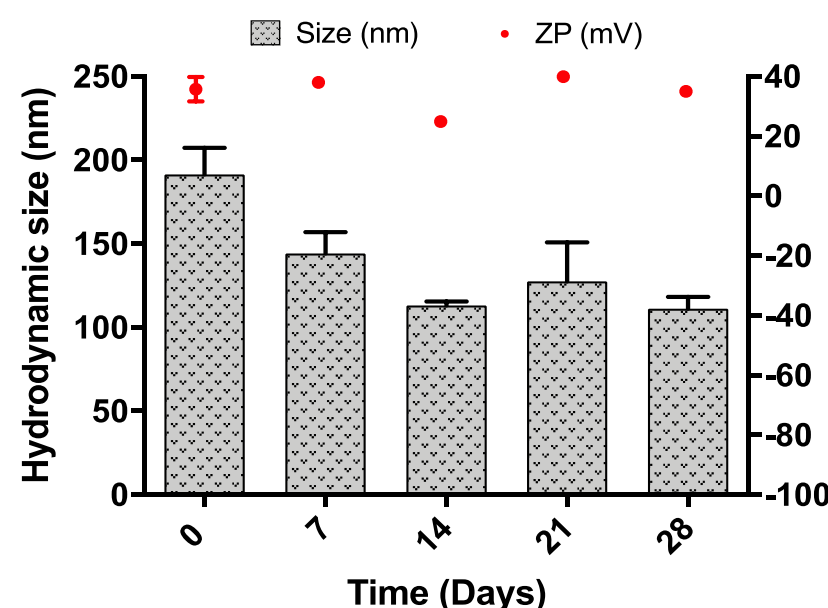

B

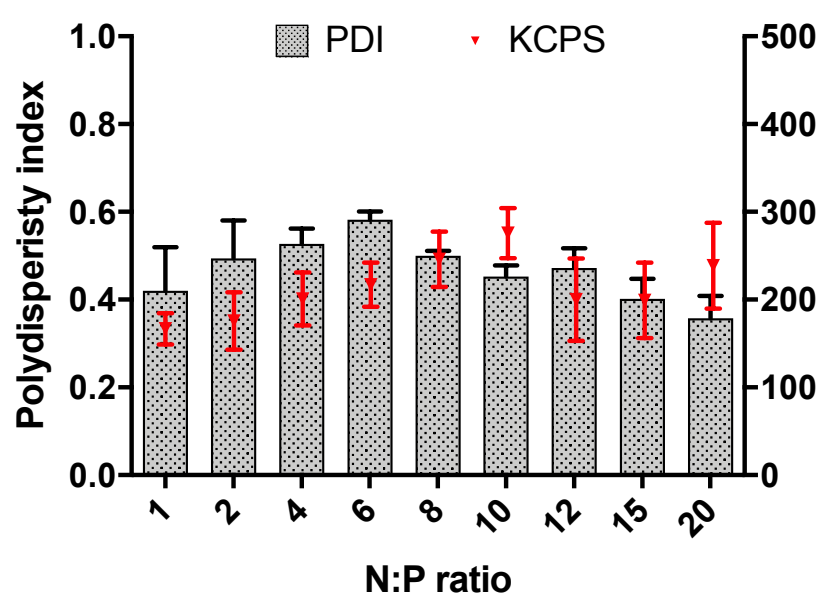

D

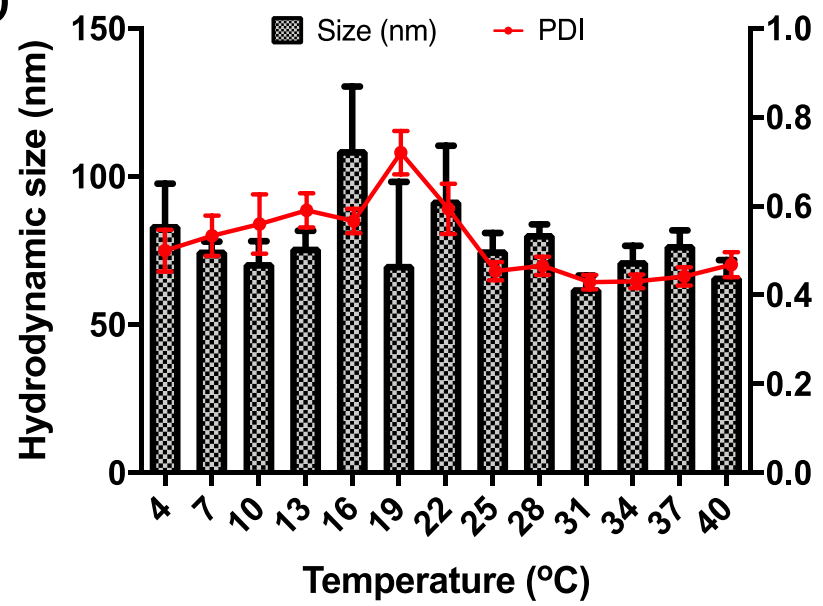

$\mathrm{F}$

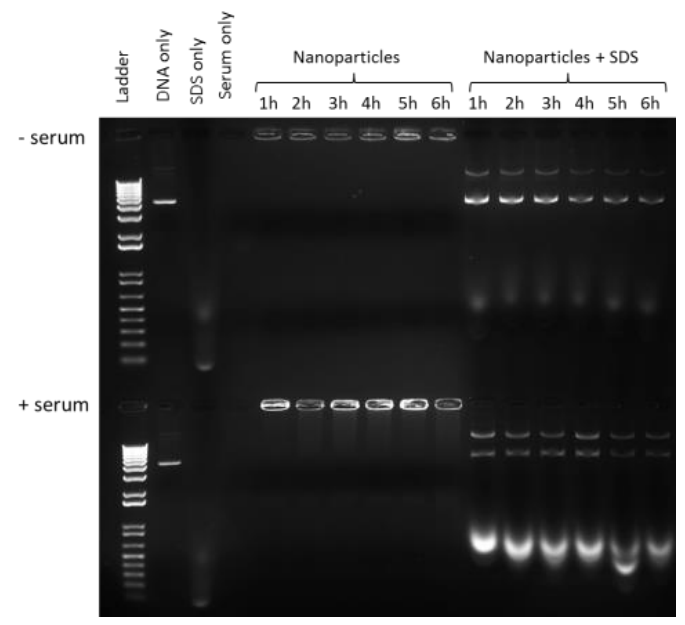

Figure 6: Physicochemical characteristics of Peptide 2. A) Mean hydrodynamic size (Z-average) and zeta potential and B) Polydispersity index (PDI) and particle count (kilocounts per second) of nanoparticles prepared with pEGFP-N1 and Pep2 at a range of $\mathrm{N}: \mathrm{P}$ ratios measured using a Malvern Zetasizer Nano ZS instrument $(n=3, \pm S E M)$. C) Representative size distribution by intensity of Pep2/pEGFP-N1 nanoparticles at N:P 10. D) mean hydrodynamic size and PDI of Pep2/pEGFP$\mathrm{N} 1$ at $\mathrm{N}: \mathrm{P} 10$ measured using a temperature trend function on the Malvern Zetasizer Nano ZS $(n=3, \pm$ SEM). E) Mean hydrodynamic size of Pep2/pEGFP-N1 at N:P 10 determined across a 28 day time period $(n=3, \pm$ SEM). F) Stability of Pep2/pEGFP-N1 at N:P 10 in the presence of foetal calf serum up to 6 hours. 
A
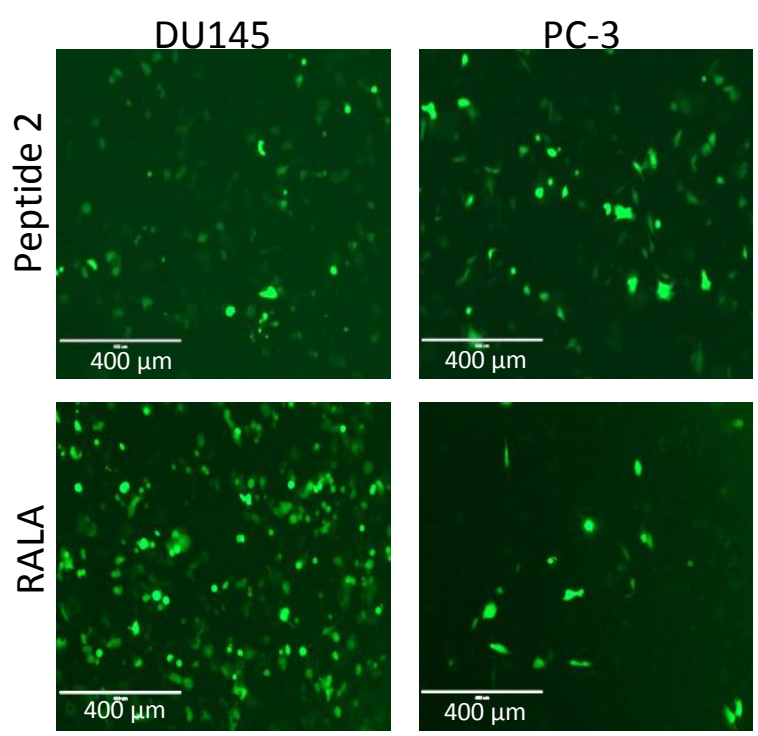

C
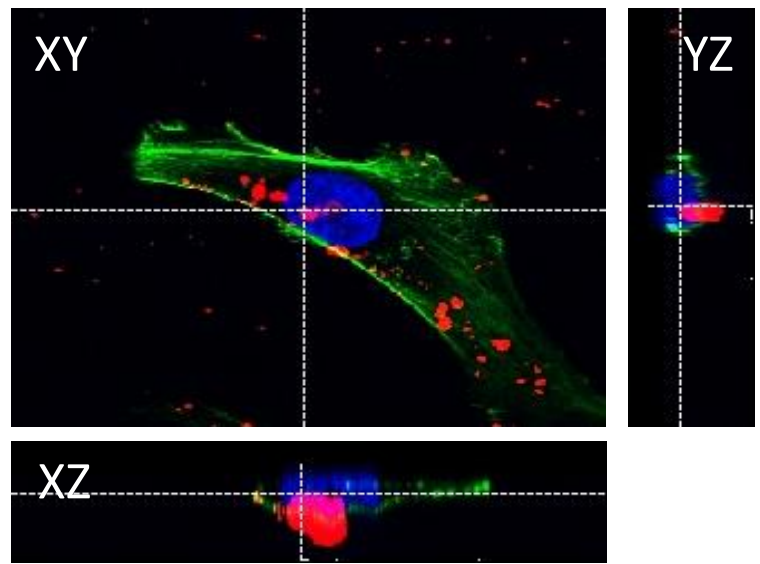

Key: Blue $=$ Nucleus stained with DAPI

Green $=$ Cytoskeleton stained with FITC Red $=$ Cy3 labelled pDNA
B
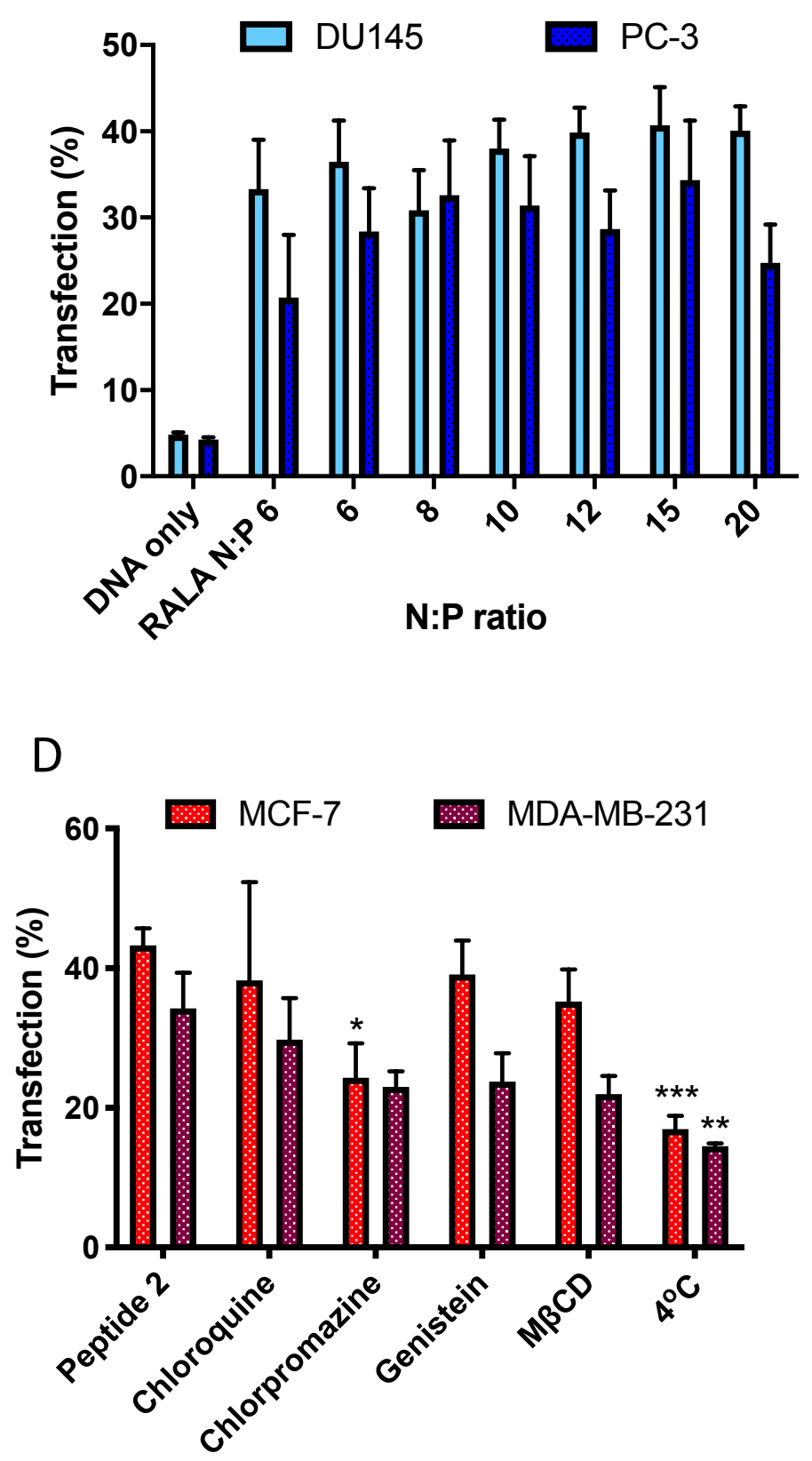

Figure 7: In vitro functionality Peptide 2. A) Light fluorescent microscopy images following transfection of DU145 and PC-3 prostate cancer cells with nanoparticles comprising pEGFP-N1 and Pep2 compared to RALA. B) Quantification of transfection efficiency in prostate cancer cells analysed by flow cytometry at $4 \%$ gating using a BD FACS Calibur ( $n=3, \pm$ SEM). C) Confocal microscopy images and orthogonal sectioning following transfection of MDA-MB-231 breast cancer cells with at N:P 10 delivering Cy3 labelled pDNA at $4 \mathrm{~h}$ post-transfection taken with a TSC SP5-Leica Microsystems confocal microscope. D) Transfection efficiency of Pep2/pEGFP-N1 complexes assessed in MCF-7 and MDA-MB-231 breast cancer cells following pre-treatment with endosomal escape and endocytosis inhibitors to determine possible cellular uptake pathway. Statistical analysis was carried out by OneWay ANOVA and Dunnett post-test $\left(*=\mathrm{P}<0.05,{ }^{* *}=\mathrm{P}<0.01,{ }^{* * *}=\mathrm{P}<0.001\right)$. 

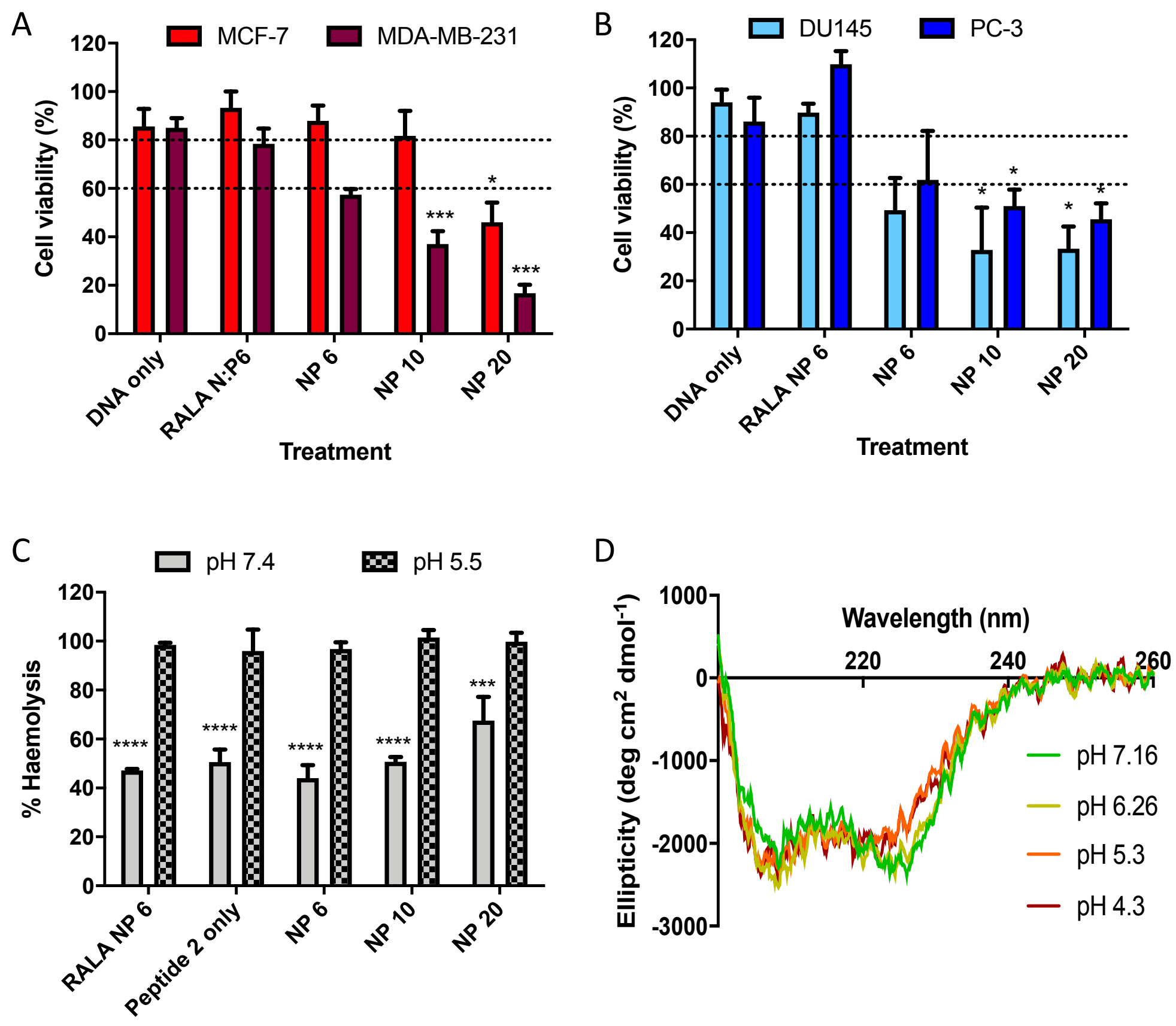

Figure 8: Cell viability of A) MCF-7 and MDA-MB-231 breast cancer cells and B) DU145 and PC-3 prostate cancer cells following transfection with Pep2 and compared to RALA ( $n=3, \pm$ SEM). Statistical analysis was carried out by One-Way ANOVA and Dunnett post-test ${ }^{*}=\mathrm{P}<0.05, * *=\mathrm{P}<0.01, * * *=$ $\mathrm{P}<0.001$ ). C) Haemolytic activity of Pep2/pEGFP-N1 on erythrocytes at pH 5.5 and $\mathrm{pH} 7.4$. \pm SEM, $\mathrm{n}=3$. Statistical analysis was carried out by One-Way ANOVA and Sidak post-test $(*=\mathrm{P}<0.05, * *=\mathrm{P}$ $<0.01, * * *=\mathrm{P}<0.001)$. D) Circular Dichroic (CD) spectra of Pep2 in the presence of $10 \mathrm{mM}$ $\mathrm{NaH} 2 \mathrm{PO} 4$ buffer containing $150 \mathrm{mM} \mathrm{NaCl}$ at various $\mathrm{pHs}$ recorded on a Jasco J-815 spectropolarimeter (Jasco International Co. Ltd., Japan). 
Click here to access/download Supplementary Material Supplementary Data.pptx 


\section{CRediT Author Statement}

Emma M. McErlean: Conceptualization, Investigation, Writing.

Cian M. McCrudden: Formal Analysis, Methodology, Validation.

John W. McBride: Methodology, Validation.

Grace Cole: Investigation, Methodology.

Vicky L. Kett: Methodology, Resources, Supervision.

Tracy Robson: Resources, Visualisation.

Nicholas J Dunne: Resources, Data Curation, Writing.

Helen O McCarthy: Conceptualization, Resources, Data Curation, Writing, Supervision 